\title{
Female Audit Partners and Extended Audit Reporting: UK Evidence
}

\author{
Tarek Abdelfattah ${ }^{1,4} \cdot$ Mohamed Elmahgoub ${ }^{2,4} \cdot$ Ahmed A. Elamer ${ }^{3,4}$
}

Received: 10 December 2019 / Accepted: 19 August 2020 / Published online: 15 September 2020

(c) The Author(s) 2020

\begin{abstract}
This study investigates whether audit partner gender is associated with the extent of auditor disclosure and the communication style regarding risks of material misstatements that are classified as key audit matters (KAMs). Using a sample of UK firms during the 2013-2017 period, our results suggest that female audit partners are more likely than male audit partners to disclose more KAMs with more details after controlling for both client and audit firm attributes. Furthermore, female audit partners are found to use a less optimistic tone and provide less readable audit reports, compared to their male counterparts, suggesting that behavioural variances between female and male audit partners may have significant implications on their writing style. Therefore, this study offers new insights on the role of audit partner gender in extended audit reporting. Our findings have important implications for audit firms, investors, policymakers and governments in relation to the development, implementation and enforcement of gender diversity.
\end{abstract}

Keywords Auditor gender $\cdot$ Key audit matters $\cdot$ Gender differences $\cdot$ Extended audit reporting $\cdot$ Tone $\cdot$ Readability $\cdot$ UK

\section{Introduction}

This study investigates how audit partner gender could influence the extent of auditor disclosure and the communication style regarding risks that are classified as key audit matters (KAMs). ${ }^{1}$ The behavioural differences between males and females have been extensively examined in the business ethics literature (Carmona et al. 2018; Kelan 2008; Qi et al. 2018). Gender-related studies in the accounting and auditing profession suggest that women tend to be more riskaverse and acting more ethically, but other studies found

Tarek Abdelfattah

tarek.abdelfattah@port.ac.uk

Mohamed Elmahgoub

mohamed.elmahgoub@bcu.ac.uk

Ahmed A. Elamer

ahmed.a.elamer@gmail.com

1 Faculty of Business and Law, University of Portsmouth, Portsmouth PO1 3DE, UK

2 Birmingham City Business School, Birmingham City University, Birmingham B47BD, UK

3 Brunel Business School, Brunel University London, Kingston Lane, Uxbridge, London UB8 3PH, UK

4 Faculty of Commerce, Mansoura University, Mansoura, Egypt no behavioural differences between genders in high-profile jobs and leadership positions (Elmagrhi et al. 2019; Lara et al. 2017; Ntim 2015; Sila et al. 2016; Zalata et al. 2019). Despite inconsistent pieces of evidence, the existing research on gender behavioural differences appears tilted in favour of the positive implications of gender diversity for auditing and financial reporting quality (Qi et al. 2018; Zalata et al. 2019). In this study, we postulate that behavioural variances between female and male in risk aversion may have significant implications for audit reporting, especially after the recent reforms.

The consequences of the financial crisis included a pressing need to disclose more client and audit-specific information (PCAOB 2016). New regulations and practices followed, including a move towards much more detailed audit reports. The UK mandated extended audit reports (EARs) ${ }^{2}$ in 2013. KAMs are essential to EARs, and auditors must use their

\footnotetext{
$\overline{1}$ IAASB uses key audit matters (KAMs) and PCAOB uses critical auditor matters (CAMs) effective from June 30, 2019 for large accelerated filers and December 15, 2020 for other companies. FRC started with risks of material misstatements (RMMs) in 2013 and then KAMs from 2016. According to FRC, KAMs are broadly equivalent to the (RMMs).

2 The International Auditing and Assurance Standards Boards (IAASB) issued its standards for EARs in 2015 (effective date of December 15, 2016); the Public Company Accounting Oversight Board (PCAOB) issued its standard for EARs in 2017 (effective date of December 15, 2017).
} 
own professional judgement and draw on personal qualities to identify and discuss these with their clients before deciding which ones to include in their EARs. This change exposes auditors to greater accountability and tempts legitimacy issues that may affect their reputation (Brasel et al. 2016; Gimbar et al. 2016; Kachelmeier et al. 2014). In response, audit firms may change their norms and working patterns (Kharuddin and Basioudis 2018; Srinidhi and Gul 2007). However, such increased demand on auditors has not yet brought commensurate concern for individual practitioners and their characteristics. The increasing diversity of practitioners means such personal characteristics need the understanding to improve processes and results. To the best of the authors' knowledge, no attempt has been made to explore the impact of auditors' personal characteristics on EAR.

Given the substantial auditing regulatory change, a number of concurrent emerging studies has investigated the determinants and consequences of the EAR. Specifically, a small strand of literature has grown that investigates how EAR could affect audit quality, audit fees and financial reporting quality (Gutierrez et al. 2018; Lennox et al. 2019; Reid et al. 2019; Sierra-Garcia et al. 2019). Sierra-Garcia et al. (2019) find that the auditor's attributes are among the factors that affect the number and type of the disclosed KAMs. This is supported by a strand of literature that shifts the focus from audit firm level to partner level as partners have different behavioural characteristics (Lennox and Wu 2018). Auditors' determination of KAMs often varies among audit partners, and understandably so given that individual characteristics influence auditors' own professional judgements (Jermakowicz et al. 2018). Female auditors are more risk-averse (Hardies et al. 2013), less overconfident (Lee et al. 2019; Ittonen and Peni 2012) and have different negotiation skills (Hardies et al. 2015). On the audit reporting model, gender behavioural differences might influence auditors' language, wording, and reporting style in EARs, but when female and male audit partners behave similarly in high-profile jobs then gender might have no effect on audit reporting or its communicative value. This study adds to this nascent research by examining auditor gender influence on the extent of disclosure and communication style regarding risks classified as KAMs in EARs.

Our study is motivated by increasing gender diversity in the business environment in general and the accounting profession in particular. Indeed, the percentage of female principals at the largest five UK audit firms has increased in recent years (FRC 2018). The UK offers an ideal setting for empirical research on auditor gender and audit reporting, given its early adoption of EARs and partner signature requirement (Carcello and Li 2013). Using a sample of UK listed firms over the period 2013-2017, we find that female audit partners tend to perceive more risks and thus disclose more KAMs and provide more detailed information about KAMs than male auditors do. On reporting style, we find female audit partners tend to deliver less readable reports than their male counterparts, and they do so in a less optimistic tone. We conduct several robustness checks to address endogeneity concerns and our results remain qualitatively unchanged, suggesting that the behavioural variances between female and male audit partners influence audit reporting.

The study contributes to the literature by providing new insights into the way partners behave. Specifically, it offers empirical evidence for gender influences on audit processes, communications, and reports. Our study extends the work of Breesch and Branson (2009) and Sierra-Garcia et al. (2019) by investigating gender differences using a large sample of real audit reports from the UK audit market. It thus responds to calls for more research on how auditor characteristics influence audit reporting decisions (Church et al. 2008) and on whether gender differences exist within highly professionalized auditor groups (Hardies et al. 2015; Bédard et al. 2019). It does similar for calls regarding audit-related readability studies (Fisher et al. 2016), as it provides initial research on the relationship gender has with linguistic style, readability, and tone of audit reports. Finally, this research explores current professional, academic, and political contentions regarding women's underrepresentation in organizations' senior management positions, especially in audit firms that face allegations of gender discrimination (Lennox and Wu 2018; Nasution and Jonnergård 2017; Dalton et al. 2014). It contributes to continuing drives for minimizing gender inequality regarding representation but also such inequality at more personal levels (e.g. providing different views from traditionally male-dominated processes and procedures). Overall, then, this study has implications for the recent auditing standards that mandated KAMs and EARs and for business ethics. It educates audit firms on potential variations in audit reporting between female and male auditors, helping them with auditor choice, audit training, and audit planning. It also helps regulators assess audit reform and the regulatory changes in audit reporting. Furthermore, this work appeals to investors, market participants, and academics who are concerned about the new audit reporting model.

The study is organized as follows. "Extant Literature and Hypotheses Development" section presents the extant empirical literature and develops the research hypotheses. "Research Method" section outlines the research design, and "Results and Discussion" section discusses the empirical findings. "Conclusion" section concludes this research.

\section{Extant Literature and Hypotheses Development}

\section{Auditor Gender and KAMs Disclosure}

Gender differences exist in financial reporting, risk management and auditing (e.g. Francoeur et al. 2019; GarciaBlandon et al. 2019; Zalata et al. 2019). For instance, 
women are more sensitive to risk, they perceive more risks, participate in less risky behaviour, and make less risky choices (Ho et al. 2015; Francis et al. 2015; Jianakoplos and Bernasek 2007). Prior studies provide evidence for female auditors being more risk-averse (Hardies et al. 2013; Ittonen et al. 2013; Nekhili et al. 2018) and more liable to personal conflicts of interest (Alderman 2017). Furthermore, female auditors detect more possible material misstatements (Breesch and Branson 2009) and more likely issue going concern opinion (Hardies et al. 2016).

Additionally, female auditors are less overconfident (Ittonen and Peni 2012) compared with their male counterparts, who may underestimate audit engagement risks and fail to assess their clients properly (Garcia-Blandon et al. 2019; Nekhili et al. 2018; Hardies et al. 2015; Owhoso and Weickgenannt 2009). Female auditors are also more effective in information processing (Chung and Monroe 2001) and audit judgements (O'Donnell and Johnson 2001). They tend to comply more with rules and regulations, have higher levels of moral reasoning, and are more ethical (Karjalainen et al. 2018).

Gender discrimination is another explanation for female auditors' behaviour. Some studies link the effect of auditor gender on audit outcomes to gender discrimination in audit firms (Lee et al. 2019; Lennox and Wu 2018; Dalton et al. 2014). Female auditors must have higher skills and conduct extra effort to reach leading positions (Nasution and Jonnergård 2017). Female auditors tend to overestimate their responsibilities and take decisions that may affect their tasks' scope and performance (Fondas and Sassalos 2000; Ittonen et al. 2013), which often means they work very hard and assign more resources to audit tasks. More generally, auditors may use KAMs disclosure to minimize their legal liability and to symbolize their effort (Kachelmeier et al. 2014; CFA Institute 2013; Vanstraelen et al. 2012).

Many researchers clearly indicate gender differences, with the implication being different reactions to new KAMs requirements will result between genders, yet previous research has neglected this. Thus, we expect that female audit partners are likely to identify more KAMs and report them in greater detail. Considering these gender differences in the literature and pursuing a further understanding of women auditors in relation to this works' aims leads to the following hypotheses:

Hypothesis 1a Female audit partners report more KAMs than male audit partners do.

Hypothesis $1 \mathbf{b}$ Female audit partners disclose the reported KAMs in greater detail than male audit partners do.

\section{Auditor Gender and Writing Style}

Debates on gender differences in language styles have permeated psychological, linguistics, communications, and feminist studies (Leaper and Ayres 2007; Leaper and Robnett 2011), with women being more likely to adopt a subjective and evaluative explanatory mode. They also approach their interpretations more creatively (Breesch and Branson 2009), which fits the socioemotional role (Wood 1966), and they use supporting language strategies that imply involvement rather than males' provocative language strategies (Breesch and Branson 2009). These language variances increase with fewer limitations on language use (Newman et al. 2008).

Males and females also have differing semantic purposes when creating sentences, as women's writings use more uncertainty verb phrases (Newman et al. 2008; Mulac and Lundell 1994), though some studies nevertheless find men and women use language similarly (e.g. Thomson and Murachver 2001).

Effective writing relates to tone (Jones 2011), though business managers use different tones in different disclosure practices (Huang et al. 2013) and for various purposes - for example, Rogers et al. (2011) suggest optimistic language tempts greater litigation risk. Managers thus often use an optimistic tone when litigation risk is low and when they have greater strategic reporting incentives (Davis and TamaSweet 2012), though García-Sánchez et al. (2019) found female directors lowering their optimistic tone in sustainability reporting to increase their credibility. As audit partners are personally accountable for audit reports and auditor signatures have been mandated (Garcia-Blandon et al. 2019), the implication is that women's risk-averse attitude, conservatism, and overestimation of responsibilities suggest they use less optimistic language in EARs (a proposal risk aversion theory supports), but this needs exploring. As such, hypothesis $2 \mathrm{a}$ is as follows:

Hypothesis 2a Female audit partners use a less optimistic tone in EAR than their male counterparts.

Smith and Smith (1971) propose readability as a measure of the communication process in financial reports, and Barnett and Leoffler (1979) note variations regarding audit report readability levels. Hay (1998) similarly reported significant readability variances from different New Zealand audit firms. Linsley and Lawrence (2007) deem the largest UK companies' risk reporting very difficult to read and argue that disclosing more risk information will not improve communication if it is less readable.

Recent changes in audit reporting have increased technical expressions and resulted in lengthy audit reports, despite lengthy reports negatively affecting readability (Bonsall and 
Table 1 Sample selection and distribution by industry

\begin{tabular}{lll}
\hline Panel A-Sample selection procedures & Firms & Observations \\
\hline UK non-financial firms listed in FTSE ALL Shares index & 364 & 1820 \\
(-) Observations without EAR \& other auditing data & & 275 \\
(-) Observations with missing control variables & & 172 \\
Total observations & 312 & 1373 \\
\hline Panel B-Sample distribution by industry & No. of observations & $\%$ \\
\hline Basic materials & 134 & 9.76 \\
Consumer goods & 160 & 11.65 \\
Consumer services & 357 & 26 \\
Health care & 65 & 4.73 \\
Industrials & 463 & 33.72 \\
Oil and gas & 73 & 5.32 \\
Technology & 65 & 4.73 \\
Telecommunications & 26 & 1.89 \\
Utilities & 30 & 100 \\
Total & 1373 &
\end{tabular}

Miller 2017; Loughran and McDonald 2014; You and Zhang 2009). On how KAMs disclosures influence audit report readability, Smith (2019) says these have improved readability in the UK market, while Carver and Trinkle (2017) note negative effects. On gender, for Ginesti et al. (2018) the presence of female directors positively influences annual reports' readability in companies with small boardroom connections. Fisher et al.'s (2016) call for more research on audit-related readability seems logical given such mixed evidence overall, and this work more specifically analyses gender and EAR readability. Our final hypothesis is thus as follows:

Hypothesis 2b There is a significant relationship between audit partners' gender and EAR readability.

\section{Research Method}

\section{Sample and Data Collection}

Our sample begins with all non-financial UK companies listed in the London Stock Exchange (LSE) FTSE ALL Shares index over five years from 2013 to 2017 . This period follows the UK's implementation of the EAR and thus mandated auditor disclosure of KAMs, effective from the fiscal year ending on/or after September 2013. Two data types derive from three different sources: financial information from Datastream and FAME databases; and auditor-related variables (including EAR data) from companies' annual reports. The initial sample was 364 FTSE listed companies with 1820 firm-year observations before imposing any screens. After removing companies with missing data, the final sample totalled 312 non-financial companies with 1373 firm-year observations. Panel A of Table 1 gives details of the sample selection procedures; Panel B shows the industrial breakdown of the final sample based on ICB codes.

\section{Research Model Specification for H1}

The first pair of hypotheses examines the association between audit partner gender and the volume of KAMs disclosure. H1a predicts a positive relationship between female audit partners and number of KAMs disclosed. To test H1a, we first employ Model 1 to link the number of KAMs to audit partner gender and other auditor and firm-related determinants.

$$
\begin{aligned}
\text { KAM }_{i t}= & \beta_{0}+\beta_{1} \text { GENDER }_{i t}+\beta_{2} \text { RISK }_{i t}+\beta_{3} \text { ACCRUALS }_{i t} \\
& +\beta_{4} \text { GCO }_{i t}+\beta_{5} \text { AFEES }_{i t}+\beta_{6} \text { NAFEES }_{i t}+\beta_{7} \text { SWITCH }_{i t} \\
& +\beta_{8} \text { SIZE }_{i t}+\beta_{9} \text { ROA }_{i t}+\beta_{10} \text { QUICK }_{i t}+\beta_{11} \text { LOSS }_{i t} \\
& +\beta_{12} \text { DEBT } \\
& +\beta_{13} \text { SEGMENTS }_{i t} \\
& + \text { YearFixed Effects }+ \text { Industry Fixed Effects } \\
& + \text { Audit Firm Fixed Effects }+\varepsilon_{i t}
\end{aligned}
$$

Consistent with recent EAR studies (Bédard et al. 2019; Lennox et al. 2019; Sierra-Garcia et al. 2019), the dependent variable in Model 1, KAM, is the natural log of the total number of risks disclosed in the $K A M$ section of the audit report for firm $i$ during year $t .{ }^{3}$ The main independent variable of interest is GENDER, a dummy variable that equals 1 if a female audit partner audits the company and 0 otherwise.

\footnotetext{
$\overline{3}$ We used log KAMs plus one to consider cases with one KAM only.
} 
We collected auditor names from annual reports ${ }^{4}$ then we searched for them on the audit firm website or LinkedIn to identify his/her gender. H1a would be empirically supported if the coefficient on GENDER in Model 1 is significant and positive.

Model 1 also uses a range of control variables commonly used in auditing literature and EAR studies to capture other auditor and firm-related characteristics (e.g. Bédard et al. 2019; Gutierrez et al. 2018; Sierra-Garcia et al. 2019). Firmrelated variables include firm size (SIZE), firm risk (RISK), return on assets $(R O A)$, quick asset ratio (QUICK), ratio of debt to total assets $(D E B T)$, presence of a net loss in the current year (LOSS), and complexity (SEGMENTS). Extant research deems larger, leveraged, and loss-making firms more incentivized to engage in more aggressive financial reporting and to likely have more KAMs (Pinto and Morais 2019; Sierra-Garcia et al. 2019). Firm risk (RISK) proxies for the firm's operating and business risk environment; number of business segments (SEGMENTS) proxies for the firm's operating complexity; and discretionary accruals (ACCRUALS) proxy for firm's earning management practices.

Following Pinto and Morais (2019), Gutierrez et al. (2018) and Sierra-Garcia et al. (2019), we control for auditor-related variables, which include going concern opinion (GCO), audit fees (AFEES), non-audit service fees (NAFEES), and auditor switch (SWITCH). Detailed descriptions of all variables are presented in Table 2. We also control for year, industry, and audit firm fixed effects to attenuate the concern that our findings are affected by time-invariant year, industry, or audit firm characteristics. ${ }^{5}$ It is important to control for audit firm fixed effects to alleviate the concern that audit partners provide a similar level of KAMs across the audit firm as a whole regardless of audit partner gender.

The influence of auditor gender on the KAMs disclosure also evidences in the length of the auditor disclosure, reflecting the detail provided. H1b says female audit partners

\footnotetext{
4 The UK mandated audit partners signature since 2009 (Carcello and $\mathrm{Li} 2013$ ).

${ }^{5}$ We do not account for the firm fixed effect, since the independent variable of interest (i.e. gender) is a dummy variable and do not substantially vary within firms over the study period. Thus, we believe that firm fixed effect is not suitable for our dataset. Also, Lennox and $\mathrm{Wu}$ (2018) highlighted the methodology of Bertrand and Schoar (2003) and Gul et al. (2013) that "To qualify for inclusion in their sample, a partner has to meet two conditions: (1) the partner audited at least two clients (to enable the separate estimation of partner fixed effects and client fixed effects), and (2) the partner audited a client for at least 3 years and there are at least another three years in which the partner audits a different client. Thus, each partner in their sample has a minimum of six observations and two clients (pp. 10 and 13)". Actually, these conditions are not met in our sample because EAR was adopted recently in 2013 and our sample covers 5 years only. We acknowledge this as a limitation of the study.
}

disclose reported KAMs in great detail. To test H1b, Model 2 tests the relationship between the length of KAM disclosure with audit partner gender, controlling for the number of KAMs and the other auditor and firm-related determinants used in Model 1.

$$
\begin{aligned}
\text { LENGTH }_{i t}= & \beta_{0}+\beta_{1} \text { GENDER }_{i t}+\beta_{2} \text { KAM }_{i t}+\beta_{3} \text { RISK }_{i t} \\
& +\beta_{4} \text { ACCRUALS }_{i t}+\beta_{5} \text { GCO }_{i t}+\beta_{6} \text { AFEES }_{i t} \\
& +\beta_{7} \text { NAFEES }_{i t}+\beta_{8} \text { SWITCH }_{i t}+\beta_{9} \text { SIZE }_{i t} \\
& +\beta_{10} \text { ROA }_{i t}+\beta_{11} \text { QUICK }_{i t}+\beta_{12} \text { LOSS }_{i t} \\
& +\beta_{13} \text { DEBT }_{i t}+\beta_{14} \text { SEGMENTS }_{i t} \\
& + \text { Year Fixed Effects }+ \text { Industry Fixed Effects } \\
& + \text { Audit Firm Fixed Effects }+\varepsilon_{i t}
\end{aligned}
$$

In Model 2, the dependent variable is the length of KAM disclosure (LENGTH), measured by the natural logarithm of number of words in the auditor's disclosure of KAMs (De Franco et al. 2015; Twedt and Rees 2012). Similar to Model 1 , the main independent variable of interest is audit partner gender. In Model 2, H1b would be empirically supported if the coefficient on GENDER is significant and positive.

\section{Research Model Specification for $\mathrm{H} 2$}

$\mathrm{H} 2$ tests the association between gender and writing style by examining the tone $(\mathrm{H} 2 \mathrm{a})$ and readability $(\mathrm{H} 2 \mathrm{~b})$ of the audit report. H2a predicts a negative relationship between female audit partners and the use of an optimistic tone in EARs. To test H2a, Model 3 links EAR tone to audit partner gender and other auditor and firm-related characteristics.

$$
\begin{aligned}
\text { TONE }_{i t}= & \beta_{0}+\beta_{1} \text { GENDER }_{i t}+\beta_{2} \text { KAM }_{i t}+\beta_{3} \text { RISK }_{i t} \\
& +\beta_{4} \text { ACCRUALS }_{i t}+\beta_{5} \text { GCO }_{i t}+\beta_{6} A C_{-} \text {TONE } \\
& +\beta_{7} \text { AFEES }_{i t}+\beta_{8} \text { NAFEES }_{i t}+\beta_{9} \text { SWITCH }_{i t} \\
& +\beta_{10} \text { SIZE }_{i t}+\beta_{11} \text { ROA }_{i t}+\beta_{12} \text { QUICK }_{i t}+\beta_{13} \text { LOSS }_{i t} \\
& +\beta_{14} \text { DEBT }_{i t}+\beta_{15} \text { SEGMENTS }_{i t} \\
& + \text { Year Fixed Effects }+ \text { Industry Fixed Effects } \\
& + \text { Audit Firm Fixed Effects }+\varepsilon_{i t}
\end{aligned}
$$

In Model 3, the dependent variable is the auditor report tone (TONE). TONE captures the degree of auditor optimism (auditor's sentiment) in the audit report. Its calculation is based on the frequency of positive and negative words (identified according to Loughran and McDonald's $(2011)^{6}$ word dictionaries). Following Henry and Leone (2016) and El-Haj et al. (2019a, b), TONE is as follows:

\footnotetext{
${ }^{6}$ We employed the Corporate Financial Information Environment (CFIE) Final Report Structure Extractor (FRSE) (hereafter CFIEFRSE), a tool developed by El-Haj et al. (2019a, b), to calculate the word frequency of positive and negative words.
} 
Table 2 Summary of definitions and operationalization of variables

\begin{tabular}{|c|c|}
\hline Variable & Definitions and coding \\
\hline \multicolumn{2}{|c|}{ Panel A: dependent variables } \\
\hline$K A M$ & Natural logarithm of the number of key audit matters disclosed in audit report plus one for firm $i$ in year $t$ \\
\hline LENGTH & $\begin{array}{l}\text { Length of Auditor's Disclosure, which is measured by taking the natural logarithm of words number in auditor } \\
\text { disclosure of KAMs for firm } i \text { in year } t\end{array}$ \\
\hline TONE & $\begin{array}{l}\text { Tone of the auditor report computed using the following equation: (Positivity Freq - Negativity Freq)/(Positivity } \\
\text { Freq + Negativity Freq) (Automated content analysis - Auditor report) }\end{array}$ \\
\hline READABILITY & $\begin{array}{l}\text { Readability of the auditor report measured by the fog index. The fog index score is computed using this formula: } \\
\text { Fog }=0.4 \times \text { (average sentence length + percentage of complex words). This index indicates that higher score } \\
\text { mean text is harder to read (Automated content analysis }- \text { Auditor report) }\end{array}$ \\
\hline \multicolumn{2}{|c|}{ Main independent variable } \\
\hline GENDER & A dummy variable equals 1 if the auditor report is signed by a female audit partner and 0 otherwise \\
\hline \multicolumn{2}{|l|}{ Control variables } \\
\hline RISK & $\begin{array}{l}\text { Firm risk proxied by price volatility measured by a stock's average annual price movement to a high and low } \\
\text { from a mean price for each year. For example, a stock's price volatility of } 20 \% \text { indicates that the stock's annual } \\
\text { high and low price has shown a historical variation of }+20 \% \text { to }-20 \% \text { from its annual average price (Data- } \\
\text { stream: Price Volatility (WC08806)) }\end{array}$ \\
\hline ACCRUALS & $\begin{array}{l}\text { The absolute value of abnormal discretionary accruals using the performance-matched discretionary accruals of } \\
\text { Kothari et al. (2005) (All variables used in this measure are collected from Datastream) }\end{array}$ \\
\hline$G C O$ & 1 if the auditor issues a going concern decision for firm $i$ in year $t, 0$ otherwise. (FAME) \\
\hline AFEES & Audit fees measured by the natural logarithm of total audit fees for firm $i$ in year $t$. (FAME) \\
\hline NAFEES & Measured by the ratio of non-audit fees to total fees (FAME) \\
\hline AC_TONE & $\begin{array}{l}\text { Tone of the audit committee's report computed using the following equation: (Positivity Freq - Negativity Freq)/ } \\
\text { (Positivity Freq + Negativity Freq). (Automated content analysis - Audit committee report) }\end{array}$ \\
\hline AC_READABILITY & $\begin{array}{l}\text { Readability of the audit committee's report, which is measured by the Fog index. The fog index score is com- } \\
\text { puted using this formula: Fog }=0.4 \times \text { (average sentence length + percentage of complex words). This Index } \\
\text { indicates that higher score mean text is harder to read (Automated content analysis - Audit committee report) }\end{array}$ \\
\hline SWITCH & 1 if the audit partner is changed for firm $i$ in year $t, 0$ otherwise (Annual report) \\
\hline SIZE & Natural logarithm of total assets for firm $i$ in year $t$ (Datastream: WC02999) \\
\hline$R O A$ & EBIT /total assets for firm $i$ in year $t$ (Datastream: WC01250/WC02999) \\
\hline$Q U I C K$ & $\begin{array}{l}\text { The ratio of current assets less inventories to current liabilities for firm } i \text { in year } t \text { (Datastream: (WC02201- } \\
\text { WC02101)/ WC03101) }\end{array}$ \\
\hline$D E B T$ & DEBT is the ratio of total debt to total assets for firm $i$ in year $t$. (Datastream: WC03255/WC02999) \\
\hline LOSS & 1 if firm $i$ has negative income in year $t, 0$ otherwise (Datastream: WC01751) \\
\hline SEGMENTS & Complexity measured by number of firm segments. (Annual report) \\
\hline FEMALE_AC & Ratio of female audit committee members to audit committee size for firm $i$ in year $t$ (Annual report) \\
\hline INDUSTRY & Industry fixed effects based on the ICB \\
\hline$Y E A R$ & Year fixed effects \\
\hline AUDITOR & Audit firm fixed effects \\
\hline
\end{tabular}

Tone $_{i t}=\frac{\text { No. of positive words }- \text { No. of negative words }}{\text { Total of positive and negative words }}$

Model 3's main independent variable is audit partner gender (GENDER) and $\mathrm{H} 2 \mathrm{a}$ would be empirically supported if the GENDER coefficient is significant and negative. The study employs various control variables commonly used in previous studies to capture auditor and firm-related characteristics. Following Smith (2019), we control for firm size in the auditor tone model. Larger firms are prestigious clients with stronger bargaining power over their auditors (Casterella et al. 2004; Fernando et al. 2010). Additionally, they have higher information quality (Atiase 1985; Lee and Park 2019), and higher analyst following (Christensen et al. 2004). We also control for other firm characteristics included in Models 1 and 2 as they affect the auditor work and can be reflected in the auditor report tone. Davis et al. (2015) suggest including firm performance variables to capture the effects of current performance on reporting tone, with ( $R O A$ ) capturing profitability during the current period, and QUICK and LOSS convey information about liquidity (Hayn 1995). Other literature (e.g. Cao et al. 2012; Lee and Park 2019; McGuire et al. 2012; Patelli and Pedrini 2015; Smith 2019; Veenman et al. 2011) indicates that larger, leveraged, 
and loss-making firms are more likely to engage in more aggressive financial reporting and consequently receive a negative audit tone. Model 3 includes firm risk (RISK) to proxy for firms' operating and business risk environment, number of business segments (SEGMENTS) to proxy for their operating complexity, and discretionary accruals (ACC $R U A L S$ ) to proxy for firms' earning management practices. Additionally, we control for audit committee tone ( $A C_{-}$ TONE) in Eq. (3) to capture the impact of audit committee communication with the auditor on EAR tone. Based on the UK corporate governance code and auditing standards requirements, audit committees are responsible for overseeing the relationship with external auditors who are required to communicate relevant information to the audit committee in order to help them understand the rationale of auditors' professional judgement.

To help dismiss concerns of auditor gender influence on tone being driven by omitted auditor factors, we follow Smith (2019) and Velte $(2018,2019)$ by controlling for auditor characteristics that may alter the level and/or tone of the EAR, including going concern opinion $(G C O)$, audit fees (AFEES), non-audit service fees (NAFEES), and audit partner switch (SWITCH). Finally, industry, year, and audit firm fixed effects are included to control for any variation related to industry, time and audit firm. Table 2 describes all variables.

Different language use between male and female audit partners is further examined through testing EAR readability. $\mathrm{H} 2 \mathrm{~b}$ posits that EAR readability varies between males and females. To test H2b, Model 4 links the readability of the audit report to audit partner gender, number of KAMs, and the other auditor and firm-related characteristics.

$$
\begin{aligned}
\text { READABILITY }_{i t}= & \beta_{0}+\beta_{1} \text { GENDER }_{i t}+\beta_{2} \text { KAM }_{i t}+\beta_{3} \text { RISK }_{i t} \\
& +\beta_{4} \text { ACCRUALS }_{i t}+\beta_{5} \text { GCO }_{i t}+\beta_{6} \text { AC_READABILITY }_{i t} \\
& +\beta_{7} \text { AFEES }_{i t}+\beta_{8} \text { NAFEES }_{i t}+\beta_{9} \text { SWITCH }_{i t} \\
& +\beta_{10} \text { SIZE }_{i t}+\beta_{11} \text { ROA }_{i t}+\beta_{12} \text { QUICK }_{i t}+\beta_{13} \text { LOSS }_{i t} \\
& +\beta_{14} \text { DEBT }_{i t}+\beta_{15} \text { SEGMENTS }_{i t} \\
& + \text { Year Fixed Effects }+ \text { Industry Fixed Effects } \\
& + \text { Audit Firm Fixed Effects }+\varepsilon_{i t}
\end{aligned}
$$

In Model 4, the dependent variable, READABILITY, captures the extent audit reports easily communicate their message about the audit process to their intended audience (Henry and Leone 2016; Smith and Smith 1971; Smith 2019). This is measured by the widely used Fog index score, which increases with level of difficulty (De Franco et al. 2015; Smith 2019; Smith and Smith 1971; Velte 2018). The Fog index ${ }^{7}$ formula is as follows:

\footnotetext{
7 We employed El-Haj et al.'s (2019a, b) CFIE-FRSE tool to calculate Fog index score.
}

Fog $=0.4 \times($ average sentence length + percentage_of_complex_words $)$.

Model 4's main independent variable and control variables are the same ones utilized in Model 2, apart from AC_READABILITY. Following Smith (2019), we employ the same control variables in the readability model as in the tone model because firm and auditor features that drive auditor report tone also drive auditor report complexity and readability. Audit committee readability ( $A C \_R E A D A B I L$ $I T Y)$ is used to capture the impact of audit committee communication with auditors on audit report readability. Considering that $\mathrm{H} 2 \mathrm{~b}$ does not predict a certain direction, $\mathrm{H} 2 \mathrm{~b}$ would be empirically supported if the GENDER coefficient is significant.

\section{Results and Discussion}

\section{Descriptive Statistics}

Table 3 provides descriptive statistics for all variables used in our econometric models. It shows numerous notable results representing widespread distribution of all variables. First, $K A M$ ranges from minimum 1 to maximum of 10 , with a 3.77 mean. Second, $L E N G T H$ ranges from minimum 675 words to maximum of 7421 words, with a 1116 words mean. Table 3 indicates that female audit partners audited 10\% of the sample in an increasing phenomenon. Table 3 also indicates that average audit fees is $£ 1.85$ million. Third, on average $26 \%$ of UK firms changed their audit partner over the study period. Most of the firms in our sample are profitable, with a $12 \%$ mean profitability. Finally, Table 3 also finds that $16 \%$ of the observations are unprofitable.

Furthering our analyses, we divided our sample into two sub-samples - firms audited by females (i.e. Gender $=1$ ) and males (i.e. Gender $=0$ ). Columns 6 and 7 of Table 3 include the $t$ test differences in means. The findings largely indicate substantial differences between the two sub-samples, as the means between the two groups are significantly different as follows: $K A M(0.10, p<0.10)$; LENGTH $(0.12, p<0.05)$; READABILITY $(0.36, p<0.05)$; TONE $(-0.03, p<0.05)$; RISK $(-1.24, p<0.10)$; AFEES $(-1.10, p<0.01)$; SIZE $(-0.57, p<0.01)$; and SEGMENTS $(-0.50, p<0.01)$. Essentially, firms audited by female audit partners tend to report on average more and detailed KAMs, but also provide less readable audit reports in a less optimistic tone. Overall, the findings support our predictions.

Table 4 reports the Pearson correlations between independent and control variables. It shows significant negative associations between female audit partners and firm size (SIZE) and complexity (SEGMENTS). However, there is a significant positive correlation between female audit partner and return on assets $(R O A)$. This indicates that female audit 
Table 3 Descriptive statistics and univariate analysis

\begin{tabular}{|c|c|c|c|c|c|c|c|}
\hline Variable & $N$ & Mean & SD & Min & Max & Diff in mean & $t$ test \\
\hline GENDER & 1373 & 0.10 & 0.30 & 0.00 & 1.00 & - & - \\
\hline$K A M$ & 1373 & 3.77 & 1.47 & 1.00 & 10.00 & $0.10^{*}$ & 2.27 \\
\hline LENGTH & 1365 & 1116.05 & 47.00 & 675.00 & 7421.00 & $0.12 * *$ & 2.86 \\
\hline READABILITY-Fog & 1373 & 21.10 & 1.15 & 18.71 & 28.13 & $0.36^{* *}$ & 3.31 \\
\hline TONE & 1373 & -0.55 & 0.11 & -0.80 & -0.17 & $-0.03 * *$ & -3.06 \\
\hline POSITIVITY_Freq & 1373 & 25.26 & 1.00 & 16.00 & 127.00 & 0.01 & 1.94 \\
\hline NEGATIVITY_Freq & 1373 & 86.15 & 6.00 & 60.00 & 347.00 & -0.01 & -1.84 \\
\hline$A C \_R E A D A B I L I T Y$ & 1371 & 21.77 & 1.55 & 18.70 & 27.24 & 0.03 & 0.21 \\
\hline$A C \_T O N E$ & 1371 & -0.29 & 0.18 & -0.77 & 0.56 & $-0.04 *$ & -2.49 \\
\hline RISK & 1373 & 26.91 & 8.77 & 10.75 & 61.49 & $1.24 *$ & 2.40 \\
\hline ACCRUALS & 1373 & 0.04 & 0.05 & 0.00 & 0.80 & 0.00 & 0.66 \\
\hline$G C O$ & 1373 & 0.02 & 0.12 & 0.00 & 1.00 & 0.00 & 0.42 \\
\hline AFEES (Million) & 1373 & 1.85 & 4.14 & 0.03 & 39.72 & $-1.10^{* * *}$ & -9.59 \\
\hline NAFEES \% & 1373 & 0.28 & 0.19 & 0.00 & 0.92 & -0.01 & -0.55 \\
\hline SWITCH & 1373 & 0.26 & 0.44 & 0.00 & 1.00 & 0.07 & 1.88 \\
\hline SIZE & 1373 & 14.06 & 1.68 & 9.43 & 19.51 & $-0.57 * * *$ & -6.12 \\
\hline$R O A$ & 1373 & 0.12 & 0.23 & -0.86 & 3.71 & 0.07 & 1.74 \\
\hline$Q U I C K$ & 1373 & 1.22 & 1.27 & 0.09 & 28.64 & -0.05 & -0.75 \\
\hline LOSS & 1373 & 0.16 & 0.37 & 0.00 & 1.00 & 0.05 & 1.55 \\
\hline$D E B T$ & 1373 & 0.22 & 0.17 & 0.00 & 1.10 & -0.01 & -0.50 \\
\hline SEGMENTS & 1373 & 2.57 & 2.03 & 1.00 & 10.00 & $-0.50 * * *$ & -3.95 \\
\hline
\end{tabular}

Variables are defined as follows: audit partner gender (GENDER), number of key audit matters (KAM), length of auditor's disclosure ( $L E N G T H)$, readability of auditor's report using Fog (READABILITY-Fog), net tone (TONE), number of positive words (POSITIVITY_Freq), number of negative words (NEGATIVITY_Freq), readability of audit committee's report using Fog (AC_READABILITY), audit committee's net tone (AC_TONE), Firm risk (RISK), audit quality (ACCRUALS), going concern opinion (GCO), audit fees (AFEES), non-audit service fees (NAFEES), auditor Switch $(S W I T C H)$, firm size (SIZE), the return on assets $(R O A)$, quick asset ratio ( $Q U I C K)$, the presence of a net loss in the current year (LOSS), the ratio of debt to total assets $(D E B T)$, and complexity (SEGMENTS) partners are more likely to audit smaller, less complicated, and profitable firms. Overall, the correlation matrix does not show any potential serious multicollinearity problems.

\section{Regression Results}

Tables 5 reports OLS regression results for the four models previously explained. A pooled cross-sectional regression analysis with industry, year and audit firm fixed effect is employed, and White's t-statistic adjustments are used to mitigate heteroscedasticity problems that frequently exist in cross-sectional level-based designs. Number of KAMs, length of KAMs' disclosure, EAR tone, and EAR readability are the dependent variables in columns 1-6 of Table 5 .

\section{Number and Length of KAMs Disclosure Analysis}

Columns 1 and 2 of Table 5 show the regression estimates for female audit partners (GENDER) and number and length of KAMs. The adjusted $R^{2}$ are 0.36 and 0.56 , respectively. Results (Column 1) suggest the coefficient of female audit partners (0.056) is positive and significant at the $p<0.01$ level, which supports Hypothesis 1a: female audit partners disclose more KAMs than males do, after controlling auditee-related risk. With respect to economic significance, the number of key audit matters is about $6 \%$ higher for firms audited by females. Given that the average number of KAMs in the sample is about 3.77, our estimates suggest that female auditors disclose on average about $3.77 \times 1.06=4$ KAMs . Female audit partners thus perceive and report relatively more potential risks than male do, supporting the gender effect evidence reported in prior audit partner studies (e.g. Breesch and Branson 2009; Garcia-Blandon et al. 2019; Hardies et al. 2015; Ittonen et al. 2013). While the estimation results of number of KAMs deem not economically significant, there is a need to consider that the maximum number of KAMs is relatively limited. To ensure that auditors do not retreat into the boilerplate disclosures, the FRC discouraged auditors from disclosing all their significant risks as KAMs, after recognizing this case in the first year of mandating KAMs (ACCA 2018). Additionally, auditors may present 


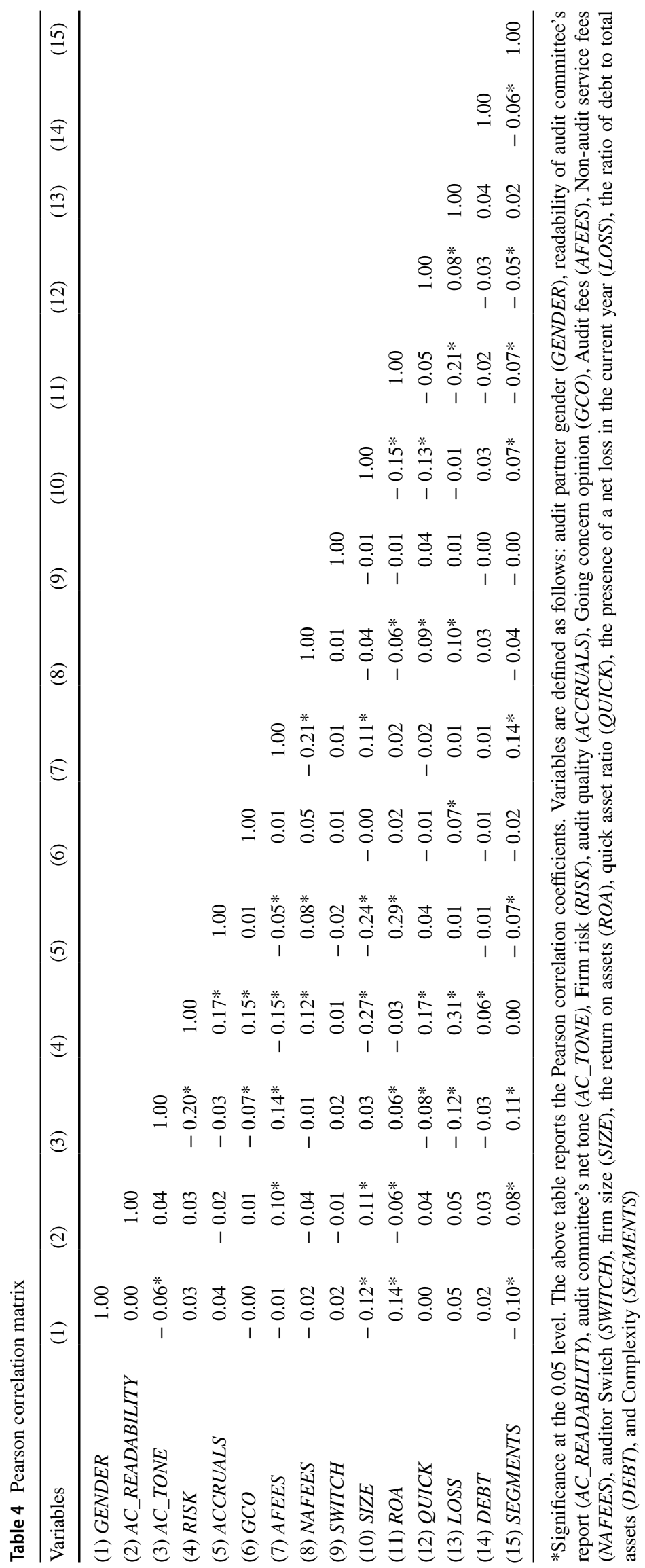


Table 5 The impact of audit partner gender on the extended audit reporting

\begin{tabular}{|c|c|c|c|c|c|c|}
\hline Dependent variable & $\begin{array}{l}\text { H1a } \\
\text { (1) }\end{array}$ & $\begin{array}{l}\mathrm{H} 1 \mathrm{~b} \\
(2)\end{array}$ & $\begin{array}{l}\mathrm{H} 2 \mathrm{a} \\
(3)\end{array}$ & $\begin{array}{l}\mathrm{H} 2 \mathrm{a} \\
(4)\end{array}$ & $\begin{array}{l}\mathrm{H} 2 \mathrm{~b} \\
(5)\end{array}$ & $\begin{array}{l}\mathrm{H} 2 \mathrm{~b} \\
(6)\end{array}$ \\
\hline & KAMs & Length & Tone & Tone & Readability & Readability \\
\hline GENDER & $\begin{array}{l}0.056^{* * * *} \\
(2.63)\end{array}$ & $\begin{array}{l}0.127 * * * \\
(4.08)\end{array}$ & $\begin{array}{l}-0.031 * * * \\
(-3.27)\end{array}$ & $\begin{array}{l}-0.030 * * * \\
(-3.12)\end{array}$ & $\begin{array}{l}0.214 * * \\
(2.15)\end{array}$ & $\begin{array}{l}0.228 * * \\
(2.26)\end{array}$ \\
\hline$K A M$ & & $\begin{array}{l}0.214 * * * \\
(20.90)\end{array}$ & $\begin{array}{l}-0.000 \\
(-0.15)\end{array}$ & $\begin{array}{l}-0.003 \\
(-1.22)\end{array}$ & $\begin{array}{l}0.015 \\
(0.62)\end{array}$ & $\begin{array}{l}0.011 \\
(0.45)\end{array}$ \\
\hline AC_TONE & & & $\begin{array}{l}0.077 * * * \\
(4.38)\end{array}$ & $\begin{array}{l}0.070 * * * \\
(3.97)\end{array}$ & & \\
\hline AC_READABILITY & & & & & $\begin{array}{l}0.121 * * * \\
(5.50)\end{array}$ & $\begin{array}{l}0.122 * * * \\
(5.51)\end{array}$ \\
\hline RISK & $\begin{array}{l}0.002 * \\
(1.90)\end{array}$ & $\begin{array}{l}0.005^{* * * *} \\
(3.12)\end{array}$ & $\begin{array}{l}-0.000 \\
(-0.89)\end{array}$ & $\begin{array}{l}-0.000 \\
(-0.44)\end{array}$ & $\begin{array}{l}0.003 \\
(0.88)\end{array}$ & $\begin{array}{l}0.004 \\
(1.03)\end{array}$ \\
\hline ACCRUALS & $\begin{array}{l}0.071 \\
(0.53)\end{array}$ & $\begin{array}{l}0.661 * * \\
(2.54)\end{array}$ & $\begin{array}{l}0.124 * * \\
(2.03)\end{array}$ & $\begin{array}{l}0.126^{* *} \\
(2.12)\end{array}$ & $\begin{array}{l}-0.059 \\
(-0.13)\end{array}$ & $\begin{array}{l}-0.131 \\
(-0.28)\end{array}$ \\
\hline$G C O$ & $\begin{array}{l}0.025 \\
(0.55)\end{array}$ & $\begin{array}{l}0.036 \\
(0.39)\end{array}$ & & $\begin{array}{l}-0.062 * * * \\
(-3.94)\end{array}$ & & $\begin{array}{l}0.097 \\
(0.43)\end{array}$ \\
\hline AFEES & $\begin{array}{l}0.066^{* * * *} \\
(8.78)\end{array}$ & $\begin{array}{l}0.028 * * \\
(2.43)\end{array}$ & & $\begin{array}{l}0.014 * * * \\
(4.29)\end{array}$ & & $\begin{array}{l}0.053^{*} \\
(1.85)\end{array}$ \\
\hline NAFEES & $\begin{array}{l}-0.016 \\
(-0.43)\end{array}$ & $\begin{array}{l}0.032 \\
(0.53)\end{array}$ & & $\begin{array}{l}-0.009 \\
(-0.61)\end{array}$ & & $\begin{array}{l}0.233 \\
(1.47)\end{array}$ \\
\hline SWITCH & $\begin{array}{l}-0.023 \\
(-1.47)\end{array}$ & $\begin{array}{l}0.020 \\
(0.86)\end{array}$ & & $\begin{array}{l}0.001 \\
(0.18)\end{array}$ & & $\begin{array}{l}0.005 \\
(0.08)\end{array}$ \\
\hline SIZE & $\begin{array}{l}0.184 * * * \\
(13.74)\end{array}$ & $\begin{array}{l}0.124 * * * \\
(5.49)\end{array}$ & $\begin{array}{l}0.002 \\
(0.91)\end{array}$ & $\begin{array}{l}0.003 \\
(0.42)\end{array}$ & $\begin{array}{l}0.042 * \\
(1.77)\end{array}$ & $\begin{array}{l}0.102 * \\
(1.68)\end{array}$ \\
\hline$R O A$ & $\begin{array}{l}-0.120 * * * \\
(-4.65)\end{array}$ & $\begin{array}{l}-0.040 \\
(-0.82)\end{array}$ & $\begin{array}{l}-0.015 \\
(-1.33)\end{array}$ & $\begin{array}{l}-0.022 * \\
(-1.94)\end{array}$ & $\begin{array}{l}0.048 \\
(0.56)\end{array}$ & $\begin{array}{l}0.036 \\
(0.42)\end{array}$ \\
\hline QUICK & $\begin{array}{l}0.011 \\
(1.64)\end{array}$ & $\begin{array}{l}0.015 \\
(1.46)\end{array}$ & $\begin{array}{l}-0.006 \\
(-1.54)\end{array}$ & $\begin{array}{l}-0.006 \\
(-1.55)\end{array}$ & $\begin{array}{l}0.067 * * * \\
(3.79)\end{array}$ & $\begin{array}{l}0.063 * * * \\
(3.43)\end{array}$ \\
\hline LOSS & $\begin{array}{l}0.061 * * * \\
(3.02)\end{array}$ & $\begin{array}{l}0.089 * * * \\
(2.83)\end{array}$ & $\begin{array}{l}-0.016^{*} \\
(-1.91)\end{array}$ & $\begin{array}{l}-0.017 * * \\
(-2.07)\end{array}$ & $\begin{array}{l}-0.042 \\
(-0.52)\end{array}$ & $\begin{array}{l}-0.055 \\
(-0.68)\end{array}$ \\
\hline$D E B T$ & $\begin{array}{l}0.024 \\
(0.54)\end{array}$ & $\begin{array}{l}-0.001 \\
(-0.02)\end{array}$ & $\begin{array}{l}-0.025 \\
(-1.36)\end{array}$ & $\begin{array}{l}-0.024 \\
(-1.31)\end{array}$ & $\begin{array}{l}0.085 \\
(0.48)\end{array}$ & $\begin{array}{l}0.066 \\
(0.36)\end{array}$ \\
\hline SEGMENTS & $\begin{array}{l}0.005 \\
(1.47)\end{array}$ & $\begin{array}{l}0.013 * * \\
(2.18)\end{array}$ & $\begin{array}{l}0.001 \\
(0.77)\end{array}$ & $\begin{array}{l}0.001 \\
(0.69)\end{array}$ & $\begin{array}{l}0.028 * * \\
(1.97)\end{array}$ & $\begin{array}{l}0.029 * * \\
(2.00)\end{array}$ \\
\hline CONSTANT & $\begin{array}{l}1.423 * * * \\
(23.20)\end{array}$ & $\begin{array}{l}4.941 * * * \\
(31.79)\end{array}$ & $\begin{array}{l}-0.631 * * * \\
(-14.98)\end{array}$ & $\begin{array}{l}-0.592 * * * \\
(-25.72)\end{array}$ & $\begin{array}{l}18.009 * * * \\
(32.69)\end{array}$ & $\begin{array}{l}18.434 * * * \\
(34.28)\end{array}$ \\
\hline Year fixed effects & Included & Included & Included & Included & Included & Included \\
\hline Industry fixed effects & Included & Included & Included & Included & Included & Included \\
\hline $\begin{array}{l}\text { Audit firm fixed } \\
\text { effects }\end{array}$ & Included & Included & Included & Included & Included & Included \\
\hline Observations & 1373 & 1365 & 1373 & 1373 & 1373 & 1373 \\
\hline Max VIF & 1.63 & 1.91 & 1.83 & 1.85 & 1.90 & 1.92 \\
\hline$F$ stat & 31.76 & 55.87 & 9.48 & 10.46 & 17.36 & 15.70 \\
\hline$p$ value & $<.001$ & $<.001$ & $<.001$ & $<.001$ & $<.001$ & $<.001$ \\
\hline Adjusted $R^{2}$ & $36 \%$ & $56 \%$ & $12 \%$ & $14 \%$ & $21 \%$ & $22 \%$ \\
\hline
\end{tabular}

The above table represents regression coefficients and $t$ statistics in parentheses $* p<0.10 ; * * p<0.05 ; * * * p<0.01$. See Table 2 for the definitions of each variable
KAMs in an aggregated format that may affect the number of KAMs.
Column 2 of Table 5 presents Model (2)'s findings on whether female audit partners (GENDER) disclose more detailed KAMs $(L E N G T H)$. It shows the coefficient of 
females as significantly positive $(0.127)$ at the $p<0.01$ level, indicating that female audit partners provide more details about KAMs than males do. With regard to economic significance, our evidence is significant because it implies that the length of the disclosed KAMs is $12.7 \%$ higher for firms audited by a female audit partner. Given that the average length of KAMs in the sample is about 1116 , our estimates suggest that female auditors disclose about $1116 \times 1.127=1258$ words as average length of the disclosed KAMs. Noticeably, this quantity is economically and statistically significant, given the limited number of EAR pages. This result strongly supports Hypothesis $1 \mathrm{~b}$ and is consistent with the idea of female audit partners being risk-averse. Females' lengthy KAMs disclosures signal their effort expended in the audit process to provide higher audit quality and minimize their legal liability exposure (Doxey 2014; Twedt and Rees 2012). This is consistent with previous evidence provided for female audit partners overestimating their responsibilities, exerting more effort, and assigning more resources to audit tasks (Chung and Monroe 2001; Ittonen et al. 2013; Ittonen and Peni 2012; O'Donnell and Johnson 2001). It also matches predictions for gender-based variances in risk aversion having significant implications for the audit process and, consequently, auditor disclosures and audit quality.

These findings contribute to extant research on gender diversity and current debates concerning female audit partners' auditing role. In this sense, recent auditing and financial reporting quality literature has emphasized that gender diversity can influence information asymmetries, going concern opinions, earnings management, and quality of audit services (Abbott et al. 2012; Cameran et al. 2018; Elamer et al. 2020a, b; Fondas and Sassalos 2000; Garcia-Blandon et al. 2019; Hardies et al. 2016; Ittonen et al. 2013).

\section{The Tone and Readability of Auditor's Report Analysis}

Columns 3 and 4 of Table 5 present the regression findings for female audit partners (GENDER) and audit report tone. Optimistic (positiveness) tone is used to proxy for EAR tone. The adjusted $R^{2}$ for the models is 0.12 and 0.14 , respectively. Column 3 of Table 5 presents the basic line regression model (that only controls for client-related characteristics) and shows a significant negative relationship between GENDER and EAR tone at $1 \%$, which associates females with a less optimistic tone. Hence, hypothesis H2a is accepted. We also extend this model by adding other auditor-related controls in Column 4 of Table 5. Results remain unchanged under these alternative specifications. ${ }^{8}$ The economic significance

\footnotetext{
8 As a robustness check, we control for audit report length in Model 3. Our results (untabulated) remain qualitatively unchanged under these alternative specifications.
}

of this evidence is that the optimistic tone of the EAR is $3 \%$ lower for firms audited by a female. Given that the average optimistic tone of the EAR in the sample is about -0.55 , our estimates suggest that female auditors use less optimistic tone in the EAR by about $-0.55 \times 3 \%=0.02$. Consistent with prior studies (e.g. Burke et al. 2019; Palvia et al. 2015), the use of less optimistic language by female audit partners can be justified in view of their risk-averse attitude to reduce their legal liability exposure.

Columns 5 and 6 of Table 5 present our results for Hypotheses $2 b$, which predicted that the EAR readability level would vary between male and female audit partners. The adjusted $R^{2}$ are 0.21 and 0.22 , respectively. Column 5 presents the basic line regression model (that only controls for client-related characteristics) and shows a significant positive association between female audit partners (GEN$D E R)$ and EAR readability at 5\%, indicating that females tend to produce less readable reports. We also extend this model by adding other auditor-related controls in Column 6 of Table 5. The results remain robust under these alternative specifications and strongly support Hypothesis $2 \mathrm{~b}$. The economic implication of this evidence is that the readability of the EAR is $22.8 \%$ lower for firms audited by a female. Given that the average readability of the EAR in the sample is about 21.10 , our estimates suggest that female auditors EAR readability about $21.10 \times 1.228=25.91$. Evidently, this extent is economically significant, plus its statistical significance. This finding is generally against Kim and Chung (2014) and Ginesti et al. (2018), who document positive links between women's participation in general and financial reporting readability. A potential explanation could be that female audit partners provide lengthy KAMs disclosure ${ }^{9}$ that are too detailed and long for readers to process easily, hence negatively affect the readability of the audit report (Bonsall and Miller 2017; Loughran and McDonald 2014; You and Zhang 2009). Additionally, the assurance role of female auditors and the language complexity can explain the less readable audit report. This is consistent with Carver and Trinkle (2017), who report KAMs' negative impact on report readability.

Overall, the findings of this study support the behavioural economics and cognitive psychology research that proposes significant gender-based variances in risk tolerance (e.g. Abbott et al. 2012; Ittonen et al. 2013; Nettle 2007; Pierce and Sweeney 2010; Schmitt et al. 2008). Our results propose that behavioural variances between men and women may

\footnotetext{
${ }^{9}$ Disclosing more information about perceived risks (i.e. auditor assessment of client risk in the KAMs section) involves technical information and expressions that could increase the difficulty of audit report readability.
} 
have significant implications for audit partners' perception of risk and their writing style. Recent research (e.g. BenAmar et al. 2017; Bravo and Alcaide-Ruiz 2019; Elamer et al. 2019, 2020a, b; Elmagrhi et al. 2019; Garcia-Blandon et al. 2019; Knechel et al. 2015; Sierra-Garcia et al. 2019) has emphasized that personal attributes such as gender diversity can have a significant consequence on the audit quality and financial reporting. In this respect, our results add to this stream of research as we documented that auditor gender plays a significant role in driving audit reporting, thus helping academics, regulators and policymakers better evaluate the audit reporting style of audit partners. They also contribute to the current political debate about females' underrepresentation at senior levels of the audit and accounting profession.

Finally, regarding control variables, we found RISK, AFEES, SIZE, QUICK, LOSS, and DEBT statistically significant and positively related to the number, length, tone, and readability of disclosed KAMs, implying that UK firms with high levels of these variables more likely get greater KAMs detail.

\section{Additional Analyses}

We employ a battery of additional tests to ascertain the robustness of our results. First, under the main analysis, on whether female audit partners more likely disclose more KAMs, our analysis suggests, so far, that this is so. Furthermore, we assert that having a female audit partner reinforces the RISK-KAM association, based on the assumption that female audit partners disclose KAMs that properly capture firm risk. To empirically test this, we include the $G E N D E R \times R I S K$, a variable created by interacting auditor gender (GENDER) and firm risk (RISK). The coefficient of interest, $\beta_{3}$, presents the incremental effect of GENDER on the relationship between firm risk (RISK) and the current number of KAMs $(K A M)$. A positive coefficient $\beta_{3}$ shows a higher relationship between RISK and KAM for firms audited by a female partner, and vice versa. We use Model 5 to test this assumption as follows.

$$
\begin{aligned}
\text { KAM }_{i t}= & \beta_{0}+\beta_{1} \text { GENDER }_{i t}+\beta_{2} \text { RISK }_{i t}+\beta_{3}{\text { GENDER } \times \text { RISK }_{i t}} \\
& +\beta_{4} \text { ACCRUALS }_{i t}+\beta_{5} \text { GCO }_{i t}+\beta_{6} \text { AFEES }_{i t}+\beta_{7} \text { NAFEES }_{i t} \\
& +\beta_{8} \text { SWITCH }_{i t}+\beta_{9} \text { SIZE }_{i t}+\beta_{10} \text { ROA }_{i t}+\beta_{11} \text { QUICK }_{i t} \\
& +\beta_{12} \text { LOSS }_{i t}+\beta_{13} D E B T_{i t}+\beta_{14} \text { SEGMENTS }_{i t} \\
& + \text { Year Fixed Effects }+ \text { Industry Fixed Effects } \\
& + \text { Audit Firm Fixed Effects }+\varepsilon_{i t}
\end{aligned}
$$

Column 1 of Table 6 gives the estimation results. The coefficient $\beta_{3}$ is positive and statistically significant at the $5 \%$ level, offering empirical evidence for the higher number of KAMs in female-audited firms strongly relating to a firm's risk. This finding supports Hypothesis 1a that the RISK-KAM connection is significantly and positively contingent on GENDER, implying that female audit partners are more risk-averse and sensitive to litigation risk. Specifically, the female audit partners report captures more of the firm's risk.

Second, our findings thus far show that female auditors influence the extent of KAM reporting, likely disclosing more KAM details than males do. Alternatively, though, this could indicate a different style, with some auditors writing more but shorter KAMs. To address this possibility, we calculate $L E N G T H$ as the natural log of the average length of an individual KAM rather than total KAMs length. The results (column 2 of Table 6) confirm the positive relationship between female audit partners and KAMs disclosure level $(p<0.01)$. This implies that females disclose more details to accommodate and explain their perceived risk, and it supports the notion of female audit partners being more riskaverse and sensitive to litigation risk; hence they are highly motivated to signal their effort and provide detailed KAMs disclosure. Remarkably, Column 2 of Table 6 reports the coefficient of KAM as significantly negative $(-0.057)$ at the $p<0.01$ level, suggesting that, on average, increased KAM numbers decrease the average length of an individual KAM.

Third, while the main analysis indicates a less optimistic tone in female audit partners' reports, results do not evidence their use of the positive or/and negative tone separately. To investigate these tones separately, we split the tone into two groups: negative and positive. Following Smith (2019), positive tone (Positive_words) uses the following formula:

Positive_words $_{i t}=\frac{\text { No. of positive words }}{\text { Total audit report words }}$

Similarly, calculating negative tone (Negative_words) involves this formula:

Negative_words $s_{i t}=\frac{\text { No. of negative words }}{\text { Total audit report words }}$

Columns 3 and 4 of Table 6 report the adjusted $R^{2}$ as 0.12 and 0.16 , respectively. Column 5 of Table 6 shows a significant positive (negative) relationship between female auditors and the use of negative (positive) tone. Hence, we accept hypothesis $\mathrm{H} 2 \mathrm{a}$ about female audit partners using a less optimistic tone. These findings suggest that female audit partners are using more negative words/tone in their EAR.

Fourth, we next test the robustness of the audit report readability using the measure of the Flesch-Kincaid Reading Ease Score (Kincaid et al. 1975) as an alternate proxy for readability, which is calculated as follows: 
Table 6 Additional analysis

\begin{tabular}{|c|c|c|c|c|c|}
\hline Dependent variables & $\begin{array}{l}\mathrm{H} 1 \mathrm{a} \\
(1)\end{array}$ & $\begin{array}{l}\mathrm{H} 1 \mathrm{~b} \\
(2)\end{array}$ & $\begin{array}{l}\mathrm{H} 2 \mathrm{a} \\
(3)\end{array}$ & $\begin{array}{l}\mathrm{H} 2 \mathrm{a} \\
(4)\end{array}$ & $\begin{array}{l}\mathrm{H} 2 \mathrm{~b} \\
(5)\end{array}$ \\
\hline & KAMs & Average length & Positive words & Negative words & $\begin{array}{l}\text { Readability } \\
\text { (Flesch) }\end{array}$ \\
\hline GENDER & $\begin{array}{l}-0.001 \\
(-0.09)\end{array}$ & $\begin{array}{l}0.111 * * * \\
(3.70)\end{array}$ & $\begin{array}{l}-0.000 * \\
(-1.92)\end{array}$ & $\begin{array}{l}0.001 * * * \\
(2.66)\end{array}$ & $\begin{array}{l}-0.622 * \\
(-1.85)\end{array}$ \\
\hline RISK & $\begin{array}{l}0.022 * \\
(1.70)\end{array}$ & $\begin{array}{l}0.004 * * * \\
(2.73)\end{array}$ & $\begin{array}{l}0.000 \\
(0.55)\end{array}$ & $\begin{array}{l}0.000 * * \\
(2.45)\end{array}$ & $\begin{array}{l}0.011 \\
(0.78)\end{array}$ \\
\hline$G E N D E R \times R I S K$ & $\begin{array}{l}0.023 * * \\
(2.34)\end{array}$ & & & & \\
\hline$K A M$ & & $\begin{array}{l}-0.057 * * * \\
(-5.29)\end{array}$ & $\begin{array}{l}-0.000 \\
(-0.15)\end{array}$ & $\begin{array}{l}0.000 * * * \\
(2.76)\end{array}$ & $\begin{array}{l}-0.312 * * * \\
(-3.08)\end{array}$ \\
\hline AC_TONE & & & $\begin{array}{l}0.081 * * * \\
(4.22)\end{array}$ & $\begin{array}{l}0.084 * * * \\
(3.83)\end{array}$ & \\
\hline AC_READABILITY & & & & & $\begin{array}{l}0.159 * * * \\
(5.12)\end{array}$ \\
\hline ACCRUALS & $\begin{array}{l}0.074 \\
(0.55)\end{array}$ & $\begin{array}{l}0.587 * * \\
(2.27)\end{array}$ & $\begin{array}{l}0.000 \\
(0.30)\end{array}$ & $\begin{array}{l}-0.007 * * * \\
(-2.99)\end{array}$ & $\begin{array}{l}0.477 \\
(0.29)\end{array}$ \\
\hline$G C O$ & $\begin{array}{l}0.026 \\
(0.58)\end{array}$ & $\begin{array}{l}0.005 \\
(0.05)\end{array}$ & $\begin{array}{l}-0.000 \\
(-1.45)\end{array}$ & $\begin{array}{l}0.004 * * * \\
(5.21)\end{array}$ & $\begin{array}{l}0.096 \\
(0.08)\end{array}$ \\
\hline AFEES & $\begin{array}{l}0.066^{* * * *} \\
(8.77)\end{array}$ & $\begin{array}{l}0.028 * * \\
(2.43)\end{array}$ & $\begin{array}{l}0.000 * * * \\
(4.20)\end{array}$ & $\begin{array}{l}-0.000 \\
(-0.20)\end{array}$ & $\begin{array}{l}-0.425^{* * *} \\
(-3.81)\end{array}$ \\
\hline NAFEES & $\begin{array}{l}-0.017 \\
(-0.46)\end{array}$ & $\begin{array}{l}0.073 \\
(1.22)\end{array}$ & $\begin{array}{l}-0.000 \\
(-1.06)\end{array}$ & $\begin{array}{l}-0.001 \\
(-1.19)\end{array}$ & $\begin{array}{l}-0.612 \\
(-1.14)\end{array}$ \\
\hline SWITCH & $\begin{array}{l}-0.023 \\
(-1.48)\end{array}$ & $\begin{array}{l}0.030 \\
(1.32)\end{array}$ & $\begin{array}{l}-0.000 \\
(-0.38)\end{array}$ & $\begin{array}{l}-0.000 \\
(-1.24)\end{array}$ & $\begin{array}{l}-0.034 \\
(-0.15)\end{array}$ \\
\hline SIZE & $\begin{array}{l}0.184 * * * \\
(13.71)\end{array}$ & $\begin{array}{l}0.127 * * * \\
(5.77)\end{array}$ & $\begin{array}{l}-0.000 \\
(-0.18)\end{array}$ & $\begin{array}{l}-0.000 \\
(-0.72)\end{array}$ & $\begin{array}{l}-0.932 * * * \\
(-3.65)\end{array}$ \\
\hline$R O A$ & $\begin{array}{l}-0.120^{* * *} \\
(-4.66)\end{array}$ & $\begin{array}{l}0.037 \\
(0.69)\end{array}$ & $\begin{array}{l}-0.001 * * * \\
(-4.11)\end{array}$ & $\begin{array}{l}-0.001 \\
(-0.97)\end{array}$ & $\begin{array}{l}0.103 \\
(0.37)\end{array}$ \\
\hline$Q U I C K$ & $\begin{array}{l}0.011 \\
(1.64)\end{array}$ & $\begin{array}{l}0.010 \\
(1.10)\end{array}$ & $\begin{array}{l}-0.000 \\
(-0.79)\end{array}$ & $\begin{array}{l}0.000 * * \\
(2.08)\end{array}$ & $\begin{array}{l}-0.185^{* * *} \\
(-3.21)\end{array}$ \\
\hline LOSS & $\begin{array}{l}0.060 * * * \\
(2.96)\end{array}$ & $\begin{array}{l}0.108 * * * \\
(3.45)\end{array}$ & $\begin{array}{l}0.000 \\
(0.15)\end{array}$ & $\begin{array}{l}0.001 * * * \\
(4.18)\end{array}$ & $\begin{array}{l}0.237 \\
(0.79)\end{array}$ \\
\hline$D E B T$ & $\begin{array}{l}0.023 \\
(0.52)\end{array}$ & $\begin{array}{l}-0.070 \\
(-1.02)\end{array}$ & $\begin{array}{l}0.000 \\
(0.77)\end{array}$ & $\begin{array}{l}0.003 * * * \\
(3.75)\end{array}$ & $\begin{array}{l}-0.407 \\
(-0.57)\end{array}$ \\
\hline SEGMENTS & $\begin{array}{l}0.005 \\
(1.44)\end{array}$ & $\begin{array}{l}0.015^{* * * *} \\
(2.60)\end{array}$ & $\begin{array}{l}0.000 * * \\
(2.32)\end{array}$ & $\begin{array}{l}0.000 * \\
(1.69)\end{array}$ & $\begin{array}{l}-0.115^{* *} \\
(-2.16)\end{array}$ \\
\hline CONSTANT & $\begin{array}{l}1.493 * * * \\
(27.14)\end{array}$ & $\begin{array}{l}4.735 * * * \\
(32.80)\end{array}$ & $\begin{array}{l}0.005^{* * *} \\
(10.65)\end{array}$ & $\begin{array}{l}0.024 * * * \\
(22.99)\end{array}$ & $\begin{array}{l}38.508 * * * \\
(22.80)\end{array}$ \\
\hline Year fixed effects & Included & Included & Included & Included & Included \\
\hline Industry fixed effects & Included & Included & Included & Included & Included \\
\hline $\begin{array}{l}\text { Audit firm fixed } \\
\text { effects }\end{array}$ & Included & Included & Included & Included & Included \\
\hline Observations & 1373 & 1365 & 1373 & 1373 & 1373 \\
\hline Max VIF & 1.63 & 1.91 & 1.84 & 1.88 & 1.99 \\
\hline$F$ stat & 30.58 & 23.29 & 8.55 & 11.49 & 19.01 \\
\hline$p$ value & $<0.001$ & $<0.001$ & $<0.001$ & $<0.001$ & $<0.001$ \\
\hline Adjusted $R^{2}$ & $36 \%$ & $40 \%$ & $12 \%$ & $16 \%$ & $25 \%$ \\
\hline
\end{tabular}

The above table represents regression coefficients and $t$ statistics in parentheses

$* p<0.10 ; * * p<0.05 ; * * * p<0.01$. See Table 2 for the definitions of each variable 
Flesch-Kincaid Reading Ease score $=0.39 \frac{\text { Number of words }}{\text { Number of sentences }}+11.8 \frac{\text { Number of syllables }}{\text { Number of words }}-15.59$

For this, a higher score indicates easier reading. Column 5 of Table 6 presents these results and shows the coefficient of female auditor (GENDER) as negative and statistically significant at the $10 \%$ level $(\beta=-0.622)$. This generally confirms the results presented in Column 4 of Table 5 that showed a negative association between female auditors and report readability. The coefficients on the control variables in Column 5 of Table 6 generally parallel those in Column 4 in the main analysis of Table 5, implying that our conclusions were unchanged regardless of specification.

Lastly, all the dependent variables in the previous models are considered as indicator variables -1 if above the median, and 0 otherwise. Then, we conducted logistic regression models by replicating our results in Tables 5 and 6 using different variable specifications. The (untabulated) findings indicate that results reported in Tables 5 and 6 are not affected. ${ }^{10}$

\section{Endogeneity}

Although evidence so far suggests female audit partners more likely disclose more and greater detailed KAMs, provide less readable reports, and adopt less optimistic tones, dangers lurk in possible endogeneity bias from issues such as omitted variables, and self-selection bias. ${ }^{11}$ For instance, some female audit partners' appointments may not be random and self-select into certain types of firms (Lennox and Wu 2018), which may invite self-selection bias. Hardies et al. (2016) find that riskier auditees tend to be assigned to female audit partners. As presented in Table 3, several observable firm-related characteristics (e.g. RISK, SIZE, SEGMENTS) differ between female-audited and maleaudited clients. Furthermore, some omitted time-variant and time-invariant variables ${ }^{12}$ may affect results and the selection

\footnotetext{
10 As a robustness check, we rerun a pooled cross-sectional regression analysis with industry, year, and auditor fixed effect employed and standard errors clustered by firm as an alternative method. Our unreported results remain qualitatively unchanged under this alternative specification. We also winsorized all continuous variables at the 1st and 99th percentiles to address possible outliers. The untabulated results suggest this did not significantly influence our main findings.

$11 \mathrm{We}$ are grateful to three anonymous reviewers for suggesting this line of investigation.

12 We also employed firm fixed effects analysis to mitigate unobservable time-invariant factors. Although, our results hold the same direction, we did not get the expected significance for Hypothesis 1 . A plausible reason is that the percentage of treatment observations in our sample is relatively low (i.e. only 137 firm-year observations have female audit partners) and sticky across years, thus firm fixed effects specification may lack the power to detect significant results. Zhou
}

of female audit partners. To address potential endogeneities, we employ a serial of alternative ways in this section, including the use of matched sample based on propensity score matching (PSM) procedure, the instrumental variable approach using two-stage least squares (2SLS) regressions, and quasi-experimental differences-in-differences (DID) methodology around audit partner switch.

\section{Propensity Score Matching (PSM)}

One source of possible endogeneity here is selection bias. Companies audited by female partners could differ much from those audited by males. Univariate findings in Table 3 suggest a self-selection issue because such aforementioned companies may vary in several company-specific features. The significant $t$ test results (Table 3) for RISK, SIZE, and $S E G M E N T$ between male and female-audited clients support the idea that different types of clients are in fact audited by male and female audit partners, with females generally audit smaller, less complicated, and riskier firms (Garcia-Blandon et al. 2019; Hardies et al. 2015). To test whether the gender influence noticed in this study so far is driven by the different types of companies that men and women generally audit, we re-estimate the study models using a PSM sample (Garcia-Blandon et al. 2019; Hardies et al. 2015, 2016; Rosenbaum and Rubin 1983).

We start with the following Probit regression model to estimate the likelihood of hiring female audit partners. Then, we match, with replacement, each female-audited client with a male-audited client that has the nearest propensity scores generated from the estimated Probit model (Dehejia and Wahba 2002). ${ }^{13}$ We classify matched pairs with the lowest propensity score difference (i.e. $1 \%$ ), resulting in a matched sample of 172 firm-year observations.

$\overline{\text { Fwootnote } 12}$ (continued)

(2001) argues that the lack of within-firm variation in the independent variable (especially when it is a dummy variable) works against finding a significant relationship with the dependent one. Hence, the use of a firm fixed effect model may bias the results and makes it difficult to find a meaningful relationship even if one existed. This is also supported by Chen et al. (2018) and Kim et al. (2011). We acknowledge this as a limitation of the study.

13 Dehejia and Wahba (2002) show that PSM with replacement brings better results than PSM without replacement. 


$$
\begin{aligned}
\operatorname{Pr}\left[\text { GENDER }_{i t}=1\right]= & \beta_{0}+\beta_{1} \text { RISK }_{i t}+\beta_{2} \text { FSALES }_{i t}+\beta_{3} M T B_{i t} \\
& +\beta_{4} \text { SIZE }_{i t}+\beta_{5} \text { ROA }_{i t}+\beta_{6} \text { QUICK }_{i t}+\beta_{7} \text { LOSS }_{i t} \\
& +\beta_{8} D E B T_{i t}+\beta_{9} S E G M E N T S_{i t}+\beta_{10} \text { FEMALE_AC }_{i t} \\
& + \text { Year Fixed Effects }+ \text { Industry Fixed Effects } \\
& + \text { Audit Firm Fixed Effects }+\varepsilon_{i t},
\end{aligned}
$$

where the matched pairs selection model includes GENDER as the dependent variable. Model 9 includes all Model 1's firm-related control variables, as well as other variables that help to explain auditor selection. Following Lobo et al. (2017), we added two more variables: FSALES, defined as total foreign sales as a percentage of total client sales, while $M T B$ denotes market to book ratio. Hardies et al. (2015) indicate that audit committees with a significant number of female members may strongly prefer selecting a female auditor. Therefore, we added FEMALE_AC to capture the percentage of female audit committee members within each firm.

Then, we check whether the matched sample effectively controls for the diverse types of auditee of male and female audit partners. The $t$ test results for the matched sample (untabulated) show insignificant differences between male and female audit partners in all client-related variables, supporting the reliability of our matching.

Next, we employ the matched sample of 172 observations and re-estimate all models of Table 5. Table 7's results show female audit partners' coefficients as significantly and positively associated with KAMs numbers and extent of disclosure in columns 1 and 2 ( $p<0.01$, and $p<0.10$, respectively). Moreover, Columns 3 and 4 of Table 7 show female audit partners' coefficients as significantly associated with less optimistic audit report tone and readability (both at $p<0.05)$. Thus, estimates of the matched sample reinforce our main findings and show that results in Table 5 were not driven by differences in clients' characteristics.

\section{Two-stage Least Square (2SLS) ${ }^{14}$}

Hardies et al. $(2015,2016)$ argue that PSM fails to control for unobservable characteristics that could derive both dependent and independent variables and assumes potential biases to be insignificant. Therefore, it is possible that both auditors' disclosure and the selection of female auditors are significantly affected by some unobservable factors. To

\footnotetext{
14 We thank anonymous reviewers for suggesting the use of two-stage instrumental variable regressions. As a robustness check, we employ the Heckman two-step procedure as an alternative method

\begin{tabular}{|c|c|c|c|c|}
\hline \multirow[t]{2}{*}{ PSM matching } & $\begin{array}{l}\mathrm{H} 1 \mathrm{a} \\
(1)\end{array}$ & $\begin{array}{l}\mathrm{H} 1 \mathrm{~b} \\
(2)\end{array}$ & $\begin{array}{l}\mathrm{H} 2 \mathrm{a} \\
(3)\end{array}$ & $\begin{array}{l}\mathrm{H} 2 \mathrm{~b} \\
(4)\end{array}$ \\
\hline & KAMs & Length & Tone & Readability \\
\hline \multicolumn{5}{|c|}{ Dependent variables } \\
\hline GENDER & $\begin{array}{l}0.138 * * * \\
(3.19)\end{array}$ & $\begin{array}{l}0.116^{*} \\
(1.67)\end{array}$ & $\begin{array}{l}-0.038 * * \\
(-2.28)\end{array}$ & $\begin{array}{l}0.415 * * \\
(2.03)\end{array}$ \\
\hline$K A M$ & & $\begin{array}{l}0.161 * * * \\
(4.09)\end{array}$ & $\begin{array}{l}-0.009 \\
(-1.20)\end{array}$ & $\begin{array}{l}-0.158^{*} \\
(-1.78)\end{array}$ \\
\hline AC_TONE & & & $\begin{array}{l}0.031 \\
(0.54)\end{array}$ & \\
\hline $\begin{array}{l}A C \_R E A D A B I L- \\
\quad I T Y\end{array}$ & & & & $\begin{array}{l}0.208^{* * * *} \\
(3.18)\end{array}$ \\
\hline RISK & $\begin{array}{l}0.001 \\
(0.41)\end{array}$ & $\begin{array}{l}0.011^{*} \\
(1.80)\end{array}$ & $\begin{array}{l}0.001 \\
(1.09)\end{array}$ & $\begin{array}{l}-0.014 \\
(-1.09)\end{array}$ \\
\hline ACCRUALS & $\begin{array}{l}0.271 \\
(0.53)\end{array}$ & $\begin{array}{l}0.225 \\
(0.32)\end{array}$ & $\begin{array}{l}-0.105 \\
(-0.50)\end{array}$ & $\begin{array}{l}-0.526 \\
(-0.21)\end{array}$ \\
\hline$G C O$ & $\begin{array}{l}0.021 \\
(0.15)\end{array}$ & $\begin{array}{l}0.018 \\
(0.08)\end{array}$ & $\begin{array}{l}-0.007 \\
(-0.11)\end{array}$ & $\begin{array}{l}-0.611 \\
(-1.64)\end{array}$ \\
\hline AFEES & $\begin{array}{l}0.071 * * * \\
(3.32)\end{array}$ & $\begin{array}{l}0.065^{* *} \\
(2.03)\end{array}$ & $\begin{array}{l}0.035 * * * \\
(3.83)\end{array}$ & $\begin{array}{l}-0.007 \\
(-0.08)\end{array}$ \\
\hline NAFEES & $\begin{array}{l}-0.000 \\
(-0.00)\end{array}$ & $\begin{array}{l}0.117 \\
(0.70)\end{array}$ & $\begin{array}{l}0.114 * * \\
(2.21)\end{array}$ & $\begin{array}{l}0.527 \\
(0.95)\end{array}$ \\
\hline SWITCH & $\begin{array}{l}-0.015 \\
(-0.31)\end{array}$ & $\begin{array}{l}-0.016 \\
(-0.24)\end{array}$ & $\begin{array}{l}-0.022 \\
(-1.22)\end{array}$ & $\begin{array}{l}-0.033 \\
(-0.16)\end{array}$ \\
\hline SIZE & $\begin{array}{l}0.206^{* * * *} \\
(3.88)\end{array}$ & $\begin{array}{l}0.251 * * * \\
(2.65)\end{array}$ & $\begin{array}{l}0.043 * * \\
(2.23)\end{array}$ & $\begin{array}{l}-0.028 \\
(-0.11)\end{array}$ \\
\hline$R O A$ & $\begin{array}{l}-0.340 \\
(-1.20)\end{array}$ & $\begin{array}{l}-0.280 \\
(-0.68)\end{array}$ & $\begin{array}{l}-0.111 \\
(-1.19)\end{array}$ & $\begin{array}{l}-0.359 \\
(-0.41)\end{array}$ \\
\hline Quick & $\begin{array}{l}-0.023 \\
(-1.00)\end{array}$ & $\begin{array}{l}0.018 \\
(0.45)\end{array}$ & $\begin{array}{l}0.001 \\
(0.12)\end{array}$ & $\begin{array}{l}0.116 \\
(1.20)\end{array}$ \\
\hline LOSS & $\begin{array}{l}0.076 \\
(1.09)\end{array}$ & $\begin{array}{l}0.066 \\
(0.61)\end{array}$ & $\begin{array}{l}-0.014 \\
(-0.45)\end{array}$ & $\begin{array}{l}0.330 \\
(1.11)\end{array}$ \\
\hline$D E B T$ & $\begin{array}{l}0.300 * * \\
(2.24)\end{array}$ & $\begin{array}{l}-0.174 \\
(-0.81)\end{array}$ & $\begin{array}{l}-0.067 \\
(-1.20)\end{array}$ & $\begin{array}{l}0.300 \\
(0.49)\end{array}$ \\
\hline SEGMENTS & $\begin{array}{l}-0.034 * * * \\
(-2.84)\end{array}$ & $\begin{array}{l}0.022 \\
(0.87)\end{array}$ & $\begin{array}{l}0.006 \\
(1.23)\end{array}$ & $\begin{array}{l}0.071 \\
(1.02)\end{array}$ \\
\hline CONSTANT & $\begin{array}{l}1.588 * * * \\
(7.28)\end{array}$ & $\begin{array}{l}5.047 * * * \\
(7.72)\end{array}$ & $\begin{array}{l}-0.723 * * * \\
(-10.90)\end{array}$ & $\begin{array}{l}17.495^{* * * *} \\
(10.67)\end{array}$ \\
\hline Year fixed effects & Included & Included & Included & Included \\
\hline $\begin{array}{l}\text { Industry fixed } \\
\text { effects }\end{array}$ & Included & Included & Included & Included \\
\hline $\begin{array}{l}\text { Audit firm fixed } \\
\text { effects }\end{array}$ & Included & Included & Included & Included \\
\hline Observations & 172 & 172 & 172 & 172 \\
\hline$F$ stat & 7.68 & 8.38 & 5.19 & 2.27 \\
\hline$p$ value & $<0.001$ & $<0.001$ & $<0.001$ & $<0.001$ \\
\hline Adjusted $R^{2}$ & $38 \%$ & $53 \%$ & $20 \%$ & $11 \%$ \\
\hline
\end{tabular}
(Heckman 1979). Our results (untabulated) remain qualitatively unchanged under these alternative specifications.
}

Table 7 PSM estimation results for the impact of audit partner gender on the extended audit reporting

The above table represents regression coefficients and $t$ statistics in parentheses

${ }^{*} p<0.10 ; * * p<0.05 ; * * * p<0.01$. See Table 2 for the definitions of each variable 
address this concern, we employ the two-stage Least Square (2SLS) instrumental variable approach.

In the first stage, we construct a Probit regression with GENDER as the dependent variable (Hardies et al. 2015, 2016) among diverse observable variables (i.e. all control variables in our main regression). As the 2 SLS model requires an additional exogenous variable, we employ the percentage of females on an audit committee (FEMALE_AC) as an instrumental variable for two main reasons. First, it is associated with auditor gender (GENDER), our variable of interest. ${ }^{15}$ Hardies et al. (2015) indicate that audit committees with a significant number of female members may strongly prefer selecting a female auditor. Lee et al. (2019) also find female representation on the clients' board of directors increases the likelihood of having female auditors. Second, it is unlikely that the percentage of females on the audit committee to affect auditor disclosure, except through the incidence of female audit partners (Lee et al. 2019).

Following Lee et al. (2019), we test the validity of our instrumental variable. We estimate regressions of FEMALE_AC against female audit partners and get the residuals. Then, we used the residuals in our main models. The coefficient on the residual FEMALE_AC is insignificant in all of our models, suggesting that FEMALE_AC affects our dependent variables only through our main variable of interest, female audit partners. Therefore, our instrumental variable satisfies the exclusion criteria. The 2SLS model is therefore likely not to suffer from weak instrument problems. Though our additional array of checks reinforces our instrumental variable validity, we admit that determining reasonable instruments is puzzling and that their quality may be imperfect (Lee et al. 2019).

In the second stage, we use the fitted values of GEN$D E R$ from the first stage as our main independent variable and then estimate the main regression models (1-4). Results from the second stage of the 2SLS are reported in Columns (1-4) of Table 8. The results from the 2SLS procedure are highly similar to those reported in Table 5 and suggest that GENDER has a significant impact on the extent of KAMs disclosure and auditors' writing (communication) style.

\section{Difference-in-Difference (DID)}

As discussed earlier, the relationship between female audit partners and the extent of auditor disclosure and the

\footnotetext{
15 In the 1st stage, the relationship between female audit partner $(G E N D E R)$ and the percentage of female presence in audit committee (FEMALE_AC) is significant positive (at 5\%) across Models 1-4, with a related coefficients of $0.86,0.76,0.77$, and 0.82 , respectively.
}

Table 8 2SLS estimation results for the impact of audit partner gender on the extended audit reporting

\begin{tabular}{|c|c|c|c|c|}
\hline IV 2SLS & $\begin{array}{l}\text { (1) } \\
\text { KAMs }\end{array}$ & $\begin{array}{l}\text { (2) } \\
\text { Length }\end{array}$ & $\begin{array}{l}(3) \\
\text { Tone }\end{array}$ & $\begin{array}{l}\text { (4) } \\
\text { Readability }\end{array}$ \\
\hline \multicolumn{5}{|l|}{ Dependent variables } \\
\hline GENDER & $\begin{array}{l}0.379 * \\
(1.91)\end{array}$ & $\begin{array}{l}1.395 * * \\
(2.35)\end{array}$ & $\begin{array}{l}-0.510 * * * \\
(-2.86)\end{array}$ & $\begin{array}{l}4.816 * * * \\
(5.77)\end{array}$ \\
\hline$K A M$ & & $\begin{array}{l}0.175 * * * \\
(9.01)\end{array}$ & $\begin{array}{l}0.007 \\
(1.10)\end{array}$ & $\begin{array}{l}-0.064 \\
(-1.42)\end{array}$ \\
\hline AC_TONE & & & $\begin{array}{l}-0.001 \\
(-0.02)\end{array}$ & \\
\hline $\begin{array}{l}A C \_R E A D A B I L- \\
\quad I T Y\end{array}$ & & & & $\begin{array}{l}0.080 * * \\
(2.27)\end{array}$ \\
\hline RISK & $\begin{array}{l}-0.001 \\
(-0.39)\end{array}$ & $\begin{array}{l}0.003 \\
(0.87)\end{array}$ & $\begin{array}{l}-0.000 \\
(-0.14)\end{array}$ & $\begin{array}{l}0.015 * \\
(1.87)\end{array}$ \\
\hline ACCRUALS & $\begin{array}{l}0.151 \\
(0.69)\end{array}$ & $\begin{array}{l}1.580 * * * \\
(3.02)\end{array}$ & $\begin{array}{l}0.025 \\
(0.18)\end{array}$ & $\begin{array}{l}0.478 \\
(0.37)\end{array}$ \\
\hline$G C O$ & $\begin{array}{l}-0.068 \\
(-1.38)\end{array}$ & $\begin{array}{l}0.088 \\
(0.60)\end{array}$ & $\begin{array}{l}-0.025 \\
(-0.39)\end{array}$ & $\begin{array}{l}-0.619 \\
(-1.22)\end{array}$ \\
\hline AFEES & $\begin{array}{l}0.054 * * * \\
(3.87)\end{array}$ & $\begin{array}{l}0.039 \\
(1.49)\end{array}$ & $\begin{array}{l}0.012 \\
(1.24)\end{array}$ & $\begin{array}{l}0.046 \\
(0.77)\end{array}$ \\
\hline NAFEES & $\begin{array}{l}0.096^{*} \\
(1.66)\end{array}$ & $\begin{array}{l}-0.281 * * \\
(-2.32)\end{array}$ & $\begin{array}{l}-0.028 \\
(-0.69)\end{array}$ & $\begin{array}{l}0.315 \\
(1.06)\end{array}$ \\
\hline SWITCH & $\begin{array}{l}-0.025^{*} \\
(-1.65)\end{array}$ & $\begin{array}{l}-0.018 \\
(-0.49)\end{array}$ & $\begin{array}{l}0.002 \\
(0.18)\end{array}$ & $\begin{array}{l}-0.017 \\
(-0.14)\end{array}$ \\
\hline SIZE & $\begin{array}{l}0.197 * * * \\
(6.89)\end{array}$ & $\begin{array}{l}0.190 * * * \\
(3.75)\end{array}$ & $\begin{array}{l}-0.031^{*} \\
(-1.86)\end{array}$ & $\begin{array}{l}0.335 * * * \\
(2.92)\end{array}$ \\
\hline$R O A$ & $\begin{array}{l}-0.098 \\
(-0.46)\end{array}$ & $\begin{array}{l}-0.583 \\
(-1.45)\end{array}$ & $\begin{array}{l}-0.223 \\
(-1.39)\end{array}$ & $\begin{array}{l}0.780 \\
(0.82)\end{array}$ \\
\hline QUICK & $\begin{array}{l}-0.021 \\
(-0.68)\end{array}$ & $\begin{array}{l}-0.019 \\
(-0.28)\end{array}$ & $\begin{array}{l}0.002 \\
(0.09)\end{array}$ & $\begin{array}{l}-0.047 \\
(-0.36)\end{array}$ \\
\hline LOSS & $\begin{array}{l}0.049 \\
(1.53)\end{array}$ & $\begin{array}{l}0.019 \\
(0.26)\end{array}$ & $\begin{array}{l}-0.018 \\
(-0.83)\end{array}$ & $\begin{array}{l}-0.226 \\
(-1.29)\end{array}$ \\
\hline$D E B T$ & $\begin{array}{l}0.057 \\
(0.64)\end{array}$ & $\begin{array}{l}-0.145 \\
(-0.94)\end{array}$ & $\begin{array}{l}0.046 \\
(0.74)\end{array}$ & $\begin{array}{l}-0.358 \\
(-0.92)\end{array}$ \\
\hline SEGMENTS & $\begin{array}{l}0.014 * \\
(1.85)\end{array}$ & $\begin{array}{l}0.032 * * \\
(2.00)\end{array}$ & $\begin{array}{l}-0.011 * * \\
(-2.52)\end{array}$ & $\begin{array}{l}0.121 * * * \\
(3.70)\end{array}$ \\
\hline CONSTANT & $\begin{array}{l}1.241 * * * \\
(14.06)\end{array}$ & $\begin{array}{l}5.589 * * * \\
(16.25)\end{array}$ & $\begin{array}{l}-0.547^{* * *} \\
(-6.60)\end{array}$ & $\begin{array}{l}18.407 * * * \\
(20.26)\end{array}$ \\
\hline Year fixed effects & Included & Included & Included & Included \\
\hline $\begin{array}{l}\text { Industry fixed } \\
\text { effects }\end{array}$ & Included & Included & Included & Included \\
\hline $\begin{array}{l}\text { Audit firm fixed } \\
\text { effects }\end{array}$ & Included & Included & Included & Included \\
\hline Observations & 1070 & 1063 & 1070 & 1070 \\
\hline
\end{tabular}

The above table represents regression coefficients and $t$ statistics in parentheses

${ }^{*} p<0.10 ; * * p<0.05 ; * * * p<0.01$. See Table 2 for the definitions of each variable 
communication style regarding KAMs may be affected by unobservable omitted variable bias. To supplementary mitigate these concerns, we adopt a quasi-experimental differences-in-differences (DID) methodology. We follow GarciaBlandon et al. (2019), Hardies et al. (2015) and Ittonen et al. (2013) and test the abovementioned relationship by investigating whether the noted KAMs disclosure and reporting style change after a female audit partner's appointment. The DID analysis compares these before and after switches from a male-to-female audit partner with a control sample of male-to-male switches. We generate a dummy variable $M T F$, which equals 1 for a male-to-female audit partner switch and 0 for a male to a male one. This results in a sample that includes 193 male-to-male and 25 male-to-female partner switches, giving a final sample of 218 firm-year observations. Hence, $M T F$ represents the incremental variation because of switching from a male to a female audit partner. Following Hardies et al. (2015), we re-estimate the regression models in Table 5 with $M T F$ acts as the main independent variable, while the dependent and control variables are measured by the change $(\Delta)$ from year $t-1$ to year $t$, utilizing each auditee as its own control. The estimated coefficients for MTF $(0.089,-0.048$, and 0.510 , respectively) are statistically significant at $10 \%$ for Models 1, 3, and 4, respectively. In contrast, while the $M T F$ coefficient in Model 2 (0.026) has the expected sign, it is not statistically significant. These findings suggest that females disclose a higher number of KAMs, use less optimistic tone, and provide less readable disclosures following an audit partner switch, than males do. Though, given the few number of audit partner switches in our sample, causal interpretations of DID results should be made with caution since they are restricted by a lack of statistical power (Ittonen et al. 2013).

\section{Conclusion}

Although the effects of female audit partners on risk, auditor judgements, and audit quality have been fairly documented, the literature is silent on how auditor gender influences audit reporting. Thus, this study contributes to the extant literature by examining: (i) association between auditor gender and KAMs (numbers and details); and (ii) consequently, ascertaining whether auditor gender influences audit reporting style (tone and readability).

Based on a 2013-2017 sample of UK firms, the results suggest that female audit partners more likely disclose more KAMs (i.e. number and detail) than their male counterparts, after controlling for client and auditor attributes. The findings also suggest that female audit partners tend to provide less readable reports in a less optimistic tone. Our evidence tallies with the predictions that gender-based variances in cognitive information processing, litigation risk, and risk aversion may have significant implications for audit quality and EAR. This resembles empirical and experimental research on female audit partners providing higher audit quality (Garcia-Blandon et al. 2019; Ginesti et al. 2018; Hardies et al. 2016; Ittonen et al. 2013). Our results support the notion that female audit partners in the UK make different decisions regarding disclosing more quantity and greater detail about KAMs, doing so in different writing styles. These results are generally robust to alternative measures/models, self-selection bias and several endogeneities.

This study makes several new contributions to the current literature. First, it offers first-time evidence on the effect of auditor gender on KAMs in EARs. Specifically, it shows that hiring female auditors likely increases the number of and detail on KAMs, which will interest investors and regulators who are seeking ways to improve auditor reporting. Second, it evidences the impact of auditor gender on the tone and readability of audit reports, adding much to related literature. Finally, it shows how auditor gender significantly drives audit reporting, thus helping academics, regulators, and policymakers both better evaluate the audit reporting style of female audit partners and subsequently develop research, regulations, and policy-making.

Our results show women's underrepresentation in audit firms' top ranks. Thus, it supports different ideas in several countries worldwide to encourage gender diversity. These findings offer policymakers further incentive to pursue gender diversity reforms. Specifically, we hope that our results will enlighten regulators and policymakers with robust evidence in favour of improving the female auditor's representation. Distinctively, our findings can help regulators and policymakers through their revelations that behavioural variances between men and women auditors significantly influence EAR content, writing style, and disclosure levels. Our results also could help shareholders and other stakeholders recognize the importance of having female audit partners because they tend to report KAMs more closely with stakeholders' expectations.

Our findings also have a significant practical implication for audit firms by revealing the impact of female audit partners on recent audit reporting reforms. While the existing literature indicates that it is preferred to appoint female auditors, our results imply that female auditors indeed tend to report more quantity and greater detail about KAMs. We hope that our results will enlighten audit firms to offer more nuanced attention to female auditors with the aim of address the gender-based risk aversion. This study also implies that audit committees may choose female audit partners as a strategic business decision to consider gender-based risk preferences.

Though our study employs rigorous methods to examine the relationship between auditor gender and EAR, it also has several caveats that need acknowledging. First, data and 
regulations constraints limited this study to non-financial UK companies listed in FTSE ALL Shares index, so the results might not be pertinent to smaller firms. Future studies should try to investigate the EARs published by firms with different capitalizations. Second, we use a UK sample only. Future studies could examine whether specific country-level variables influence the impact of auditor gender on auditor disclosure, considering factors such as religion, culture, governance, and macro-social level dimensions. Future studies should try to expand across different legal and cultural systems to help global investors interpret auditor reports. Thirdly, subsequent studies can consider other organizational attributes that may influence KAMs, such as particular corporate governance mechanisms. Future research also could study male and female audit partners to obtain a rich understanding of how auditors' experience and attributes specifically influence the matters concerned herein. Finally, we used a particular software (i.e. CFIE-FRSE) to calculate auditor disclosure tone and readability. Automated textual analyses are an emergent strand in accounting research, so the consistent classifications are not clear to some extent. Though the fuzziness of textual analysis is not obstructing its use, nonetheless it is an attribute that may be provoked in constructing future empirical findings that are anticipated to have reliable influence and can be rationally reproduced (Loughran and McDonald 2016; Melloni et al. 2017). Future research may develop new, modified measures of auditor reporting characteristics based on manual content analysis or/and by employing our analyses with textual analysis tools other than CFIE-FRSE (e.g. DICTION).

Acknowledgements Many thanks to Professor Steven Dellaportas, the section editor, and the three anonymous reviewers for their insightful comments and suggestions. Thanks a lot to Professor Andrew Wood for his support and helpful comments. Much appreciation to Professor Steven Young and Dr Mahmoud El-Haj for their support with the CFIE tool. Also, thanks to the participants of the 29th Audit \& Assurance Conference, the 2019 British Accounting and Finance Association (BAFA) conference, the Strathclyde Business School research seminar and the University of Central Lancashire research seminar. Tarek Abdelfattah gratefully acknowledges the financial support from the Faculty of Business and Law, University of Portsmouth.

\section{Compliance with Ethical Standards}

Conflict of interest The authors declared that they have no conflict of interest.

Open Access This article is licensed under a Creative Commons Attribution 4.0 International License, which permits use, sharing, adaptation, distribution and reproduction in any medium or format, as long as you give appropriate credit to the original author(s) and the source, provide a link to the Creative Commons licence, and indicate if changes were made. The images or other third party material in this article are included in the article's Creative Commons licence, unless indicated otherwise in a credit line to the material. If material is not included in the article's Creative Commons licence and your intended use is not permitted by statutory regulation or exceeds the permitted use, you will need to obtain permission directly from the copyright holder. To view a copy of this licence, visit http://creativecommons.org/licenses/by/4.0/.

\section{References}

Abbott, L. J., Parker, S., \& Presley, T. J. (2012). Female board presence and the likelihood of financial restatement. Accounting Horizons, 26(4), 607-629.

ACCA. (2018). Key audit matters: unlocking the secrets of the audit, available at https://www.accaglobal.com/content/dam/ACCA_ Global/professional-insights/Key-audit-matters/pi-key-audit -matters.pdf.

Alderman, J. (2017). Does auditor gender influence auditor liability? Exploring the impact of the crime congruency effect on jurors' perceptions of auditor negligence. Advances in Accounting, 38, $75-87$.

Atiase, R. K. (1985). Predisclosure information, firm capitalization and security price behavior around earnings announcements. Journal of Accounting Research, 23(1), 21-36.

Barnett, A., \& Leoffler, K. (1979). Readability of accounting and auditing messages. The Journal of Business Communication, 16(3), $49-59$.

Bédard, J., Gonthier-Besacier, N., \& Schatt, A. (2019). Consequences of expanded audit reports: Evidence from the justifications of assessments in France. Auditing: A Journal of Practice \& Theory, 38(3), 23-45.

Ben-Amar, W., Chang, M., \& McIlkenny, P. (2017). Board gender diversity and corporate response to sustainability initiatives: Evidence from the carbon disclosure project. Journal of Business Ethics, 142(2), 369-383.

Bertrand, M., \& Schoar, A. (2003). Managing with style: The effect of managers on firm policies. The Quarterly Journal of Economics, 118(4), 1169-1208.

Bonsall, S. B., \& Miller, B. P. (2017). The impact of narrative disclosure readability on bond ratings and the cost of debt. Review of Accounting Studies, 22(2), 608-643.

Brasel, K., Doxey, M. M., Grenier, J. H., \& Reffett, A. (2016). Risk disclosure preceding negative outcomes: The effects of reporting critical audit matters on judgments of auditor liability. The Accounting Review, 91(5), 1345-1362.

Bravo, F., \& Alcaide-Ruiz, M. D. (2019). The disclosure of financial forward-looking information: Does the financial expertise of female directors make a difference? Gender in Management: An International Journal, 34(2), 140-156.

Breesch, D., \& Branson, J. (2009). The effects of auditor gender on audit quality. IUP Journal of Accounting Research \& Audit Practices, 8(3), 78-107.

Burke, J. J., Hoitash, R., \& Hoitash, U. (2019). Audit partner identification and characteristics: Evidence from US form AP filings. Auditing: A Journal of Practice \& Theory, 38(3), 71-94.

Cameran, M., Ditillo, A., \& Pettinicchio, A. (2018). Audit team attributes matter: How diversity affects audit quality. European Accounting Review, 27(4), 595-621.

Cao, Y., Myers, L. A., \& Omer, T. C. (2012). Does company reputation matter for financial reporting quality? Evidence from restatements. Contemporary Accounting Research, 29(3), 956-990.

Carcello, J. V., \& Li, C. (2013). Costs and benefits of requiring an engagement partner signature: Recent experience in the United Kingdom. The Accounting Review, 88(5), 1511-1546.

Carmona, S., Ezzamel, M., \& Mogotocoro, C. (2018). Gender, management styles, and forms of capital. Journal of Business Ethics, 153(2), 357-373. 
Carver, B. T., \& Trinkle, B. S. (2017). Nonprofessional investors' reactions to the PCAOB's proposed changes to the standard audit report. SSRN. https://doi.org/10.2139/ssrn.2930375.

Casterella, J. R., Francis, J. R., Lewis, B. L., \& Walker, P. L. (2004). Auditor industry specialization, client bargaining power, and audit pricing. Auditing: A Journal of Practice \& Theory, 23(1), $123-140$.

CFA Institute. (2013). Comment letter to the Financial Reporting Council on the proposed revision of ISA 700 (UK and Ireland).

Chen, J., Leung, W. S., \& Evans, K. P. (2018). Female board representation, corporate innovation and firm performance. Journal of Empirical Finance, 48, 236-254.

Christensen, T. E., Smith, T. Q., \& Stuerke, P. S. (2004). Public predisclosure information, firm size, analyst following, and market reactions to earnings announcements. Journal of Business Finance \& Accounting, 31(7-8), 951-984.

Chung, J., \& Monroe, G. S. (2001). A research note on the effects of gender and task complexity on an audit judgment. Behavioral Research in Accounting, 13(1), 111-125.

Church, B. K., Davis, S. M., \& McCracken, S. A. (2008). The auditor's reporting model: A literature overview and research synthesis. Accounting Horizons, 22(1), 69-90.

Dalton, D. W., Cohen, J. R., Harp, N. L., \& McMillan, J. J. (2014). Antecedents and consequences of perceived gender discrimination in the audit profession. Auditing: A Journal of Practice \& Theory, 33(3), 1-32.

Davis, A. K., \& Tama-Sweet, I. (2012). Managers' use of language across alternative disclosure outlets: Earnings press releases versus MD\&A. Contemporary Accounting Research, 29(3), 804-837.

Davis, A. K., Ge, W., Matsumoto, D., \& Zhang, J. L. (2015). The effect of manager-specific optimism on the tone of earnings conference calls. Review of Accounting Studies, 20(2), 639-673.

De Franco, G., Hope, O. K., Vyas, D., \& Zhou, Y. (2015). Analyst report readability. Contemporary Accounting Research, 32(1), 76-104.

Dehejia, R. H., \& Wahba, S. (2002). Propensity score-matching methods for nonexperimental causal studies. Review of Economics and Statistics, 84(1), 151-161.

Doxey, M. (2014). The effects of auditor disclosures regarding management estimates on financial statement users' perceptions and investments. SSRN: https://ssrn.com/abstract $=2181624$.

Elamer, A. A., Ntim, C. G., Abdou, H. A., Zalata, A. M., \& Elmagrhi, M. (2019). The impact of multi-layer governance on bank risk disclosure in emerging markets: The case of Middle East and North Africa. Accounting Forum, 43(2), 246-281.

Elamer, A. A., Ntim, C. G., \& Abdou, H. A. (2020a). Islamic governance, national governance, and bank risk management and disclosure in MENA countries. Business \& Society, 59(5), 914-955.

Elamer, A. A., Ntim, C. G., Abdou, H. A., Owusu, A., Elmagrhi, M., \& Ibrahim, A. E. A. (2020b). Are bank risk disclosures informative? Evidence from debt markets. International Journal of Finance \& Economics. https://doi.org/10.1002/ijfe.1849.

El-Haj, M., Alves, P., Rayson, P., Walker, M., \& Young, S. (2019a). Retrieving, classifying and analysing narrative commentary in unstructured (glossy) annual reports published as PDF files. Accounting and Business Research. https://doi. org/10.1080/00014788.2019.1609346.

El-Haj, M., Rayson, P., Walker, M., Young, S., \& Simaki, V. (2019b). In search of meaning: Lessons, resources and next steps for computational analysis of financial discourse. Journal of Business Finance \& Accounting, 46(3-4), 265-306.

Elmagrhi, M. H., Ntim, C. G., Elamer, A. A., \& Zhang, Q. (2019). A study of environmental policies and regulations, governance structures, and environmental performance: The role of female directors. Business Strategy and the Environment, 28(1), 206-220.

Fernando, G. D., Abdel-Meguid, A. M., \& Elder, R. J. (2010). Audit quality attributes, client size and cost of equity capital. Review of Accounting and Finance, 9, 363.

Financial Reporting Council (FRC). (2018). Key Facts and Trends in the Accountancy Profession. London: Financial Reporting Council.

Fisher, I. E., Garnsey, M. R., \& Hughes, M. E. (2016). Natural language processing in accounting, auditing and finance: A synthesis of the literature with a roadmap for future research. Intelligent Systems in Accounting, Finance and Management, 23(3), 157-214.

Fondas, N., \& Sassalos, S. (2000). A different voice in the boardroom: How the presence of women directors affects board influence over management. Global Focus, 12(2), 13-22.

Francis, B., Hasan, I., Park, J. C., \& Wu, Q. (2015). Gender differences in financial reporting decision making: Evidence from accounting conservatism. Contemporary Accounting Research, 32(3), $1285-1318$.

Francoeur, C., Labelle, R., Balti, S., \& Bouzaidi, S. E. (2019). To what extent do gender diverse boards enhance corporate social performance? Journal of Business Ethics, 155(2), 343-357.

Garcia-Blandon, J., Argilés-Bosch, J. M., \& Ravenda, D. (2019). Is there a gender effect on the quality of audit services? Journal of Business Research, 96, 238-249.

García-Sánchez, I. M., Suárez-Fernández, O., \& Martínez-Ferrero, J. (2019). Female directors and impression management in sustainability reporting. International Business Review, 28(2), 359-374.

Gimbar, C., Hansen, B., \& Ozlanski, M. E. (2016). The effects of critical audit matter paragraphs and accounting standard precision on auditor liability. The Accounting Review, 91(6), 1629-1646.

Ginesti, G., Drago, C., Macchioni, R., \& Sannino, G. (2018). Female board participation and annual report readability in firms with boardroom connections. Gender in Management: An International Journal, 33(4), 296-314.

Gul, F. A., Hutchinson, M., \& Lai, K. M. (2013). Gender-diverse boards and properties of analyst earnings forecasts. Accounting Horizons, 27(3), 511-538.

Gutierrez, E., Minutti-Meza, M., Tatum, K. W., \& Vulcheva, M. (2018). Consequences of adopting an expanded auditor's report in the United Kingdom. Review of Accounting Studies, 23(4), $1543-1587$.

Hardies, K., Breesch, D., \& Branson, J. (2013). Gender differences in overconfidence and risk taking: Do self-selection and socialization matter? Economics Letters, 118(3), 442-444.

Hardies, K., Breesch, D., \& Branson, J. (2015). The female audit fee premium. Auditing: A Journal of Practice \& Theory, 34(4), 171-195.

Hardies, K., Breesch, D., \& Branson, J. (2016). Do (fe) male auditors impair audit quality? Evidence from going-concern opinions. European Accounting Review, 25(1), 7-34.

Hay, D. (1998). Communication in auditors' reports: Variations in readability and the effect of audit firm structure. Asia-Pacific Journal of Accounting, 5(2), 179-197.

Hayn, C. (1995). The information content of losses. Journal of Accounting and Economics, 20(2), 125-153.

Heckman, J. J. (1979). Sample selection bias as a specification error. Econometrica: Journal of the Econometric Society, 47, 153-161.

Henry, E., \& Leone, A. J. (2016). Measuring qualitative information in capital markets research: Comparison of alternative methodologies to measure disclosure tone. The Accounting Review, 91(1), 153-178.

Ho, S. S., Li, A. Y., Tam, K., \& Zhang, F. (2015). CEO gender, ethical leadership, and accounting conservatism. Journal of Business Ethics, 127(2), 351-370. 
Huang, X., Teoh, S. H., \& Zhang, Y. (2013). Tone management. The Accounting Review, 89(3), 1083-1113.

Ittonen, K., \& Peni, E. (2012). Auditor's gender and audit fees. International Journal of Auditing, 16(1), 1-18.

Ittonen, K., Vähämaa, E., \& Vähämaa, S. (2013). Female audit partners and accruals quality. Accounting Horizons, 27(2), 205-228.

Jermakowicz, E. K., Epstein, B. J., \& Ramamoorti, S. (2018). CAM versus KAM-A distinction without a difference? Making judgments in reporting critical audit matters. The CPA Journal, 88(2), 34-40.

Jianakoplos, N. A., \& Bernasek, A. (2007). Are women more risk averse? Economic Inquiry, 36(4), 620-630.

Jones, C. G. (2011). Written and computer-mediated accounting communication skills: An employer perspective. Business Coтmunication Quarterly, 74(3), 247-271.

Kachelmeier, S. J., Schmidt, J. J., \& Valentine, K. (2014). The disclaimer effect of disclosing critical audit matters in the auditor's report. Working Paper. University of Texas at Austin.

Karjalainen, J., Niskanen, M., \& Niskanen, J. (2018). The effect of audit partner gender on modified audit opinions. International Journal of Auditing, 22(3), 449-463.

Kelan, E. K. (2008). The discursive construction of gender in contemporary management literature. Journal of Business Ethics, $81(2), 427-445$.

Kharuddin, K. A., \& Basioudis, I. G. (2018). Big 4 audit fee premiums for national-and city-specific industry leadership in the UK: Additional evidence. International Journal of Auditing, 22(1), 65-82.

Kim, Y., \& Chung, S, (2014). Are female CFOs better at improving readability of the annual reports? SSRN. https://ssrn.com/abstr act $=2402879$.

Kim, J.-B., Li, Y., \& Zhang, L. (2011). CFOs versus CEOs: Equity incentives and crashes. Journal of Financial Economics, 101(3), 713-730.

Kincaid, J. P., Fishburne Jr., R. P., Rogers, R. L., \& Chissom, B. S. (1975). Derivation of new readability formulas for navy enlisted personnel. Research Branch Report 8-75. Memphis, TN: U.S. Naval Air Station.

Knechel, R., Vanstraelen, A., \& Zerni, M. (2015). Does the identity of engagement partners matter? An analysis of audit partner reporting decisions. Contemporary Accounting Research, 32(4), $1443-1478$.

Kothari, S. P., Leone, A. J., \& Wasley, C. E. (2005). Performance matched discretionary accrual measures. Journal of Accounting and Economics, 39(1), 163-197.

Lara, J. M. G., Osma, B. G., Mora, A., \& Scapin, M. (2017). The monitoring role of female directors over accounting quality. Journal of Corporate Finance, 45, 651-668.

Leaper, C., \& Ayres, M. M. (2007). A meta-analytic review of gender variations in adults' language use: Talkativeness, affiliative speech, and assertive speech. Personality and Social Psychology Review, 11(4), 328-363.

Leaper, C., \& Robnett, R. D. (2011). Women are more likely than men to use tentative language, aren't they? A meta-analysis testing for gender differences and moderators. Psychology of Women Quarterly, 35(1), 129-142.

Lee, H. S., Nagy, A. L., \& Zimmerman, A. B. (2019). Audit partner assignments and audit quality in the United States. The Accounting Review, 94(2), 297-323.

Lee, J., \& Park, J. (2019). The impact of audit committee financial expertise on management discussion and analysis (MD\&A) tone. European Accounting Review, 28(1), 129-150.

Lennox, C., Schmidt, J., \& Thompson, A. (2019). Are expanded audit reports informative to investors? Evidence from the U.K. SSRN. https://doi.org/10.2139/ssrn.2619785.
Lennox, C. S., \& Wu, X. (2018). A review of the archival literature on audit partners. Accounting Horizons, 32(2), 1-35.

Linsley, P. M., \& Lawrence, M. J. (2007). Risk reporting by the largest UK companies: Readability and lack of obfuscation. Accounting, Auditing \& Accountability Journal, 20(4), 620-627.

Lobo, G. J., Paugam, L., Zhang, D., \& Casta, J. F. (2017). The effect of joint auditor pair composition on audit quality: Evidence from impairment tests. Contemporary Accounting Research, 34(1), $118-153$.

Loughran, T., \& McDonald, B. (2011). When is a liability not a liability? Textual analysis, dictionaries, and 10-Ks. The Journal of Finance, 66(1), 35-65.

Loughran, T., \& McDonald, B. (2014). Measuring readability in financial disclosures. The Journal of Finance, 69(4), 1643-1671.

Loughran, T., \& McDonald, B. (2016). Textual analysis in accounting and finance: A survey. Journal of Accounting Research, 54(4), $1187-1230$

McGuire, S. T., Omer, T. C., \& Sharp, N. Y. (2012). The impact of religion on financial reporting irregularities. The Accounting Review, 87(2), 645-673.

Melloni, G., Caglio, A., \& Perego, P. (2017). Saying more with less? Disclosure conciseness, completeness and balance in Integrated Reports. Journal of Accounting and Public Policy, 36(3), 220-238.

Mulac, A., \& Lundell, T. L. (1994). Effects of gender-linked language differences in adults' written discourse: Multivariate tests of language effects. Language \& Communication, 14(3), 299-309.

Nasution, D., \& Jonnergård, K. (2017). Do auditor and CFO gender matter to earnings quality? Evidence from Sweden. Gender in Management: An International Journal, 32(5), 330-351.

Nekhili, M., Javed, F., \& Chtioui, T. (2018). Gender-diverse audit partners and audit fee premium: The case of mandatory joint audit. International Journal of Auditing, 22(3), 486-502.

Nettle, D. (2007). Empathizing and systemizing: What are they, and what do they contribute to our understanding of psychological sex differences? British Journal of Psychology., 98(2), 237-255.

Newman, M. L., Groom, C. J., Handelman, L. D., \& Pennebaker, J. W. (2008). Gender differences in language use: An analysis of 14,000 text samples. Discourse Processes, 45(3), 211-236.

Ntim, C. G. (2015). Board diversity and organizational valuation: Unravelling the effects of ethnicity and gender. Journal of Management \& Governance, 19(1), 167-195.

O’Donnell, E., \& Johnson, E. N. (2001). The effects of auditor gender and task complexity on information processing efficiency. International Journal of Auditing, 5(2), 91-105.

Owhoso, V., \& Weickgenannt, A. (2009). Auditors' self-perceived abilities in conducting domain audits. Critical Perspectives on Accounting, 20(1), 3-21.

Palvia, A., Vähämaa, E., \& Vähämaa, S. (2015). Are female CEOs and chairwomen more conservative and risk averse? Evidence from the banking industry during the financial crisis. Journal of Business Ethics, 131(3), 577-594.

Patelli, L., \& Pedrini, M. (2015). Is tone at the top associated with financial reporting aggressiveness? Journal of Business Ethics, 126(1), 3-19.

Pierce, B., \& Sweeney, B. (2010). The relationship between demographic variables and ethical decision making of trainee accountants. International Journal of Auditing, 14(1), 79-99.

Pinto, I., \& Morais, A. I. (2019). What matters in disclosures of key audit matters: Evidence from Europe. Journal of International Financial Management \& Accounting, 30(2), 145-162.

Public Company Accounting Oversight Board (PCAOB). (2016). The auditor's report on an audit of financial statements when the auditor expresses an unqualified opinion and related amendments to PCAOB Standards. PCAOB Release No. 2016-003. Washington, 
D.C. https://pcaobus.org/Rulemaking/Docket034/Release-2016003-ARM.pdf.

Qi, B., Lin, J. W., Tian, G., \& Lewis, H. C. X. (2018). The impact of top management team characteristics on the choice of earnings management strategies: evidence from China. Accounting Horizons, 32(1), 143-164.

Reid, L. C., Carcello, J. V., Li, C., Neal, T. L., \& Francis, J. R. (2019). Impact of auditor report changes on financial reporting quality and audit costs: Evidence from the United Kingdom. Contemporary Accounting Research., 36(3), 1501-1539.

Rogers, J. L., Van Buskirk, A., \& Zechman, S. L. (2011). Disclosure tone and shareholder litigation. The Accounting Review, 86(6), 2155-2183.

Rosenbaum, P. R., \& Rubin, D. B. (1983). The central role of the propensity score in observational studies for causal effects. Biometrika, 70(1), 41-55.

Schmitt, D., Realo, A., Voracek, M., \& Allik, J. (2008). Why can't a man be more like a woman? Sex differences in big five personality traits across 55 cultures. Journal of Personality and Social Psychology., 94(1), 168-182.

Sierra-Garcia, L., Gambetta, N., García-Benau, M. A., \& Orta-Pérez, M. (2019). Understanding the determinants of the magnitude of entity-level risk and account-level risk key audit matters: The case of the United Kingdom. The British Accounting Review, 51(3), 227-240.

Sila, V., Gonzalez, A., \& Hagendorff, J. (2016). Women on board: Does boardroom gender diversity affect firm risk? Journal of Corporate Finance, 36, 26-53.

Smith, J., \& Smith, N. (1971). Readability: A measure of the performance of the communication function of financial reporting. The Accounting Review, 46(3), 552-561.

Smith, K. (2019). Tell me more: A content analysis of expanded auditor reporting in the United Kingdom. SSRN. https://doi.org/10.2139/ ssrn.2821399.

Srinidhi, B. N., \& Gul, F. A. (2007). The differential effects of auditors' nonaudit and audit fees on accrual quality. Contemporary Accounting Research, 24(2), 595-629.
Thomson, R., \& Murachver, T. (2001). Predicting gender from electronic discourse. British Journal of Social Psychology, 40(2), 193-208.

Twedt, B., \& Rees, L. (2012). Reading between the lines: An empirical examination of qualitative attributes of financial analysts' reports. Journal of Accounting and Public Policy, 31(1), 1-21.

Vanstraelen, A., Schelleman, C., Meuwissen, R., \& Hofmann, I. (2012). The audit reporting debate: Seemingly intractable problems and feasible solutions. European Accounting Review, 21(2), 193-215.

Veenman, D., Hodgson, A., Van Praag, B., \& Zhang, W. (2011). Decomposing executive stock option exercises: Relative information and incentives to manage earnings. Journal of Business Finance \& Accounting, 38(5-6), 536-573.

Velte, P. (2018). Does gender diversity in the audit committee influence key audit matters' readability in the audit report? UK evidence. Corporate Social Responsibility and Environmental Management, 25(5), 748-755.

Velte, P. (2019). Associations between the financial and industry expertise of audit committee members and key audit matters within related audit reports. Journal of Applied Accounting Research, 21(1), 185-200.

Wood, M. M. (1966). The influence of sex and knowledge of communication effectiveness on spontaneous speech. Word, 22(1-3), 112-137.

You, H., \& Zhang, X. J. (2009). Financial reporting complexity and investor underreaction to $10-\mathrm{K}$ information. Review of Accounting Studies, 14(4), 559-586.

Zalata, A. M., Ntim, C., Aboud, A., \& Gyapong, E. (2019). Female CEOs and core earnings quality: New evidence on the ethics versus risk-aversion puzzle. Journal of Business Ethics, 160(2), $515-534$

Zhou, X. (2001). Understanding the determinants of managerial ownership and the link between ownership and performance: comment. Journal of Financial Economics, 62(3), 559-571.

Publisher's Note Springer Nature remains neutral with regard to jurisdictional claims in published maps and institutional affiliations. 